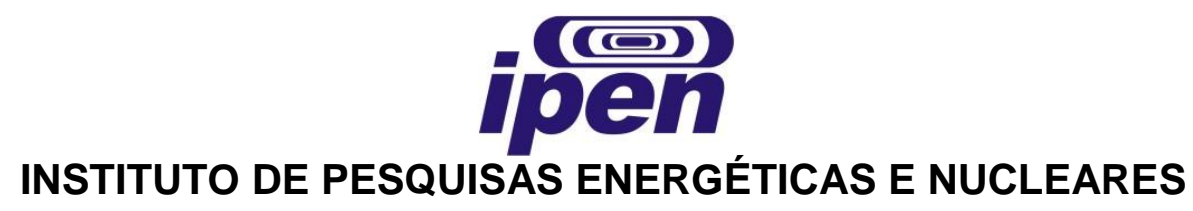

Autarquia associada à Universidade de São Paulo - USP

OBTENÇÃO DE UM MODELO HOMÓLOGO DE TERAPIA GÊNICA MEDIANTE ADMINISTRAÇÃO DIRETA DE UM PLASMÍDEO COM O GENE DO HORMÔNIO DE CRESCIMENTO MURINO EM CAMUNDONGOS ANÕES IMUNOCOMPETENTES

CLÁUDIA REGINA CECCHI

Tese apresentada como parte dos requisitos para a obtenção do Grau de Doutor em Ciências na Área de Tecnologia Nuclear-Aplicações.

Orientadora:

Dra. Cibele Nunes Peroni

São Paulo 
Dedico este trabalho às mulheres da minha vida, minha mãe Suely Mitie Fujita Cecchi, minha avó, Lourdes Bertoldo Cecchi, minha madrinha Regina Maria Cecchi Ferreira da Costa e minha irmã Michelle Cecchi, pelo apoio incondicional e amor, por estarem sempre perto nos dias mais difíceis, por todo suporte que me deram durante toda a etapa deste trabalho, e em memória ao meu amado pai José Augusto Cecchi. 


\section{Agradecimentos}

Agradeço primeiramente a Deus, por ter me dado força para me levantar todas as vezes que caí e para seguir em frente neste caminho, e também por me ter dado a capacidade de aprendizagem e o dom do trabalho em equipe.

Agradeço à Dra. Cibele Nunes Peroni, pela orientação, amizade, carinho, paciência (muita!), confiança e ensinamentos tanto na vida acadêmica quanto na vida pessoal. Por me fazer pensar, por me apoiar e ajudar até o fim. Por ser o meu "porto-seguro".

Ao Dr. Paolo Bartolini, pela orientação, ensinamentos, apoio, incentivo e estímulo para desenvolver uma parte do meu trabalho no exterior.

Ao Dr. Thomas Greysten Jensen, pela colaboração, ensinamentos, amizade e respeito, e a todo o Departamento de Biomedicina da Universidade de Aarhus, em especial à Birgit Holm Hansen, por toda amizade, carinho e apoio, ao Frederik Dagnaes-Hansen e Laars Aagaard, por toda amizade, ajuda e ensinamentos e à Maria Jacobsen, por toda ajuda na construção do plasmídeo do gene do $\mathrm{mGH}$.

Ao Dr. Alexander Augusto de Lima Jorge, pela colaboração, principalmente com idéias e sugestões valiosas neste trabalho.

À Eliza Higuti, Nélio Alessandro e Eliana Lima pela ajuda nos experimentos, companheirismo, alegria, risadas e, sobretudo, pela amizade. Pessoas mais que especiais, que entraram na minha vida através da ciência e conquistaram um grande espaço no meu coração.

À Neide e Mara, pelo cuidado com os animais, apoio nos experimentos, pela amizade e carinho.

A todos os amigos do Centro de Biotecnologia do IPEN, em especial à Flávia, Renata, Miriam, Bia, Fernanda, Natália, Taís e Laura, por toda amizade, 
carinho, companheirismo e alegria durante os almoços, à Dra. Teresa, Dr. Carlos e Dra. Kayo, pelo carinho e ensinamentos, Daniel Perez, pela ajuda e ensinamentos de estatística, e Junqueira, Johnny, Zé Maria, Márcia, Rosângela, Arlete, Rute, Lígia, Regina, Rosa, Eric, Marcos, Roberto, Flávio, Thaís, Ivette, Edna, Néia, Sandra, Marisa e Gi, e a todos os amigos que fiz durante esses 10 anos de IPEN.

A toda minha família Fujita, meu padrinho Orlando Ferreira da Costa e ao José Neves da Cruz, que sempre me apoiaram nessa escolha e a todos os amigos que estiveram do meu lado durante esses anos, compartilhando os momentos de alegria e descontração.

Ao meu namorado David Dreyer, quem encontrei no meio desse longo caminho, pelo carinho, amizade e companhia... Pelo apoio incondicional até o final dessa jornada.

Ao CNPQ pelo apoio financeiro. 
"A jornada de mil quilômetros começa com o primeiro passo" (Lao-Tsé, filósofo chinês) 


\section{SUMÁRIO}

Página

1 INTRODUÇÃO

1.1. Terapia gênica

1.1.1 Injeção hidrodinâmica........................................................................ 17

1.1.2 Eletrotransferência gênica........................................................................ 17

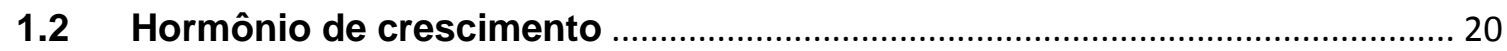

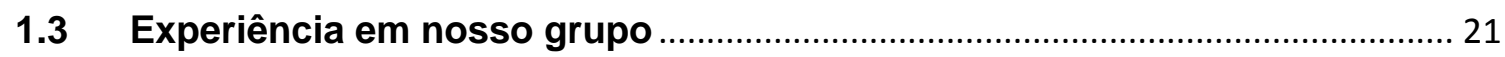

2 OBJETIVOS

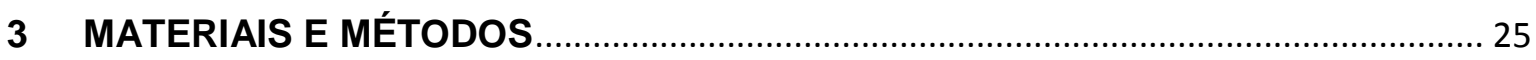

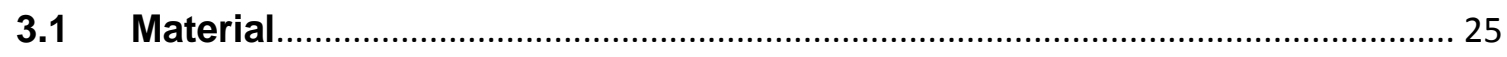

3.1.1 Equipamentos e acessórios principais …………………………….... 25

3.1.2 Principais reagentes para biologia molecular ......................................... 26

3.1.3 Principais materiais e reagentes para cultura celular ............................. 27

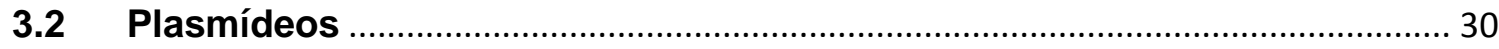

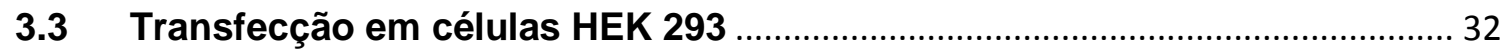

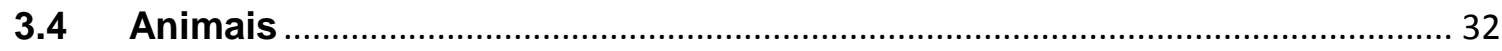

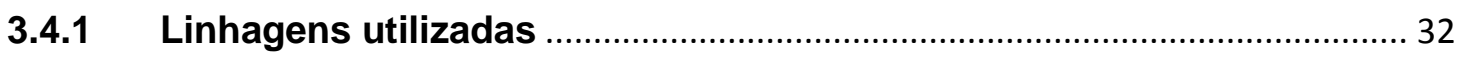

3.4.1 Condições de manutenção ……………………………………………........ 33

3.5 Injeção hidrodinâmica de plasmídeos ………………………………………….... 33

3.6 Injeção de plasmídeos associada à eletroporação ........................................... 33

3.6.1 Injeção intramuscular .............................................................................. 34

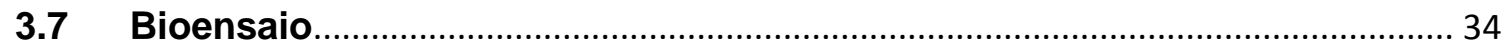

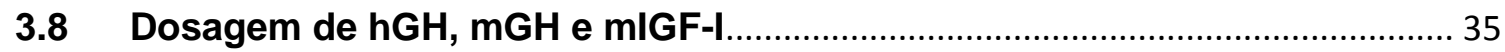

3.9 Determinação de anticorpos anti-hGH no soro dos camundongos ............... 36

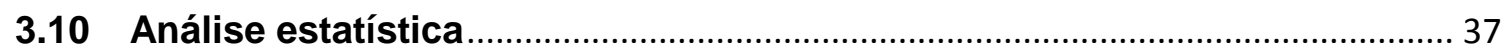

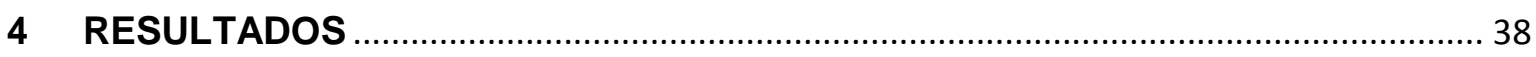

4.1 Administração de plasmídeos contendo o gene do hGH seguida por

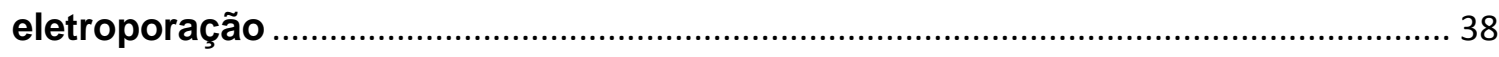

4.2 Construção do vetor pUBI-mGH-gDNA ...................................................... 41 


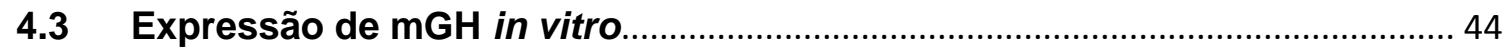

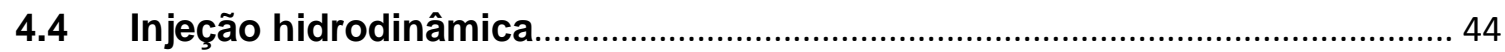

4.5 Bioensaio associado à eletrotransferência e dosagem de mIGF-I e mGH .. 47

4.6 Determinação de anticorpos anti-hGH no soro dos camundongos ............... 52

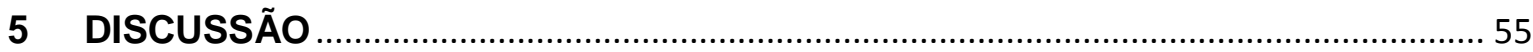

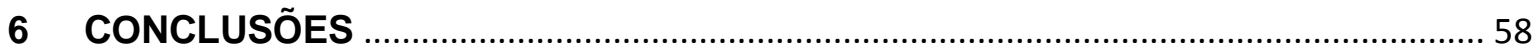

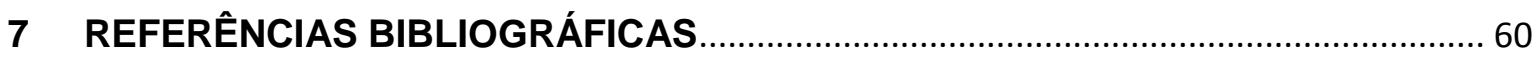


LISTA DE ABREVIATURAS E SIGLAS

Ac

BSA

cm

cpm

DGH

DNA

cDNA

gDNA

DMEM

DP

ELISA

EPO

GH

hGH

mGH

GHRH

h

HEK

I

IGF-I

IPEN

lit/lit

lit/scid

m

$\mathrm{mg}(\mu \mathrm{g})$

$\mathrm{ml}$

ms

ng

pb

PBS anticorpo

soro albumina bovina

centímetros

contagens por minuto

deficiência de hormônio de crescimento

ácido desoxirribonucléico

DNA complementar

DNA genômico

meio de cultura "Dulbecco's Modified Eagle Medium"

Desvio padrão

ensaio imunoenzimático

eritropoietina

hormônio de crescimento

hormônio de crescimento humano

hormônio de crescimento murino

hormônio liberador de hormônio do crescimento

humano

células "Human Embryonic Kidney"

lodo-125

fator de crescimento semelhante à insulina

Instituto de Pesquisas Energéticas e Nucleares

camundongos anões

camundongos anões imunodeficientes

murino

microgramas

mililitros

milisegundos

nanogramas

Pares de bases

Tampão fosfato salina 
PCR

p

PCMV

PDNA

pUBI

PEG

RNA

RIA

rpm

$\mathbf{S}$

V

VEGF reação em cadeia da polimerase

$$
\text { plasmídeo }
$$

plasmídeo com promotor do citomegalovírus plasmídeo de DNA plasmídeo com promotor da ubiquitina $\mathrm{C}$ polietilenoglicol ácido ribonucléico radioimunoensaio rotações por minuto segundos volts fator de crescimento endotelial vascular 


\title{
OBTENÇÃO DE UM MODELO HOMÓLOGO DE TERAPIA GÊNICA MEDIANTE ADMINISTRAÇÃO DIRETA DE UM PLASMÍDEO COM O GENE DO HORMÔNIO DE CRESCIMENTO MURINO EM CAMUNDONGOS ANÕES IMUNOCOMPETENTES
}

\section{CLÁUDIA REGINA CECCHI}

\begin{abstract}
RESUMO
Níveis sustentáveis de hormônio de crescimento humano (hGH) circulante e aumento de peso altamente significativo, avaliados também em comparação a repetidas injeções de hormônio, foram observados em trabalhos anteriores, baseados na eletrotransferência de DNA plasmidial no músculo de camundongos anões imunodeficientes (lit/scid). No presente trabalho, um modelo animal homólogo de terapia gênica para GH foi estudado mediante clonagem da sequência genômica do DNA de $\mathrm{GH}$ de camundongo ( $\mathrm{mGH}-\mathrm{gDNA}$ ), a qual substituiu o hGH-gDNA no vetor que havia sido utilizado em camundongos anões imunodeficientes. O novo vetor, agora nomeado UBI-mGH-gDNA, foi utilizado em camundongos anões imunocompetentes (lit/lit). Foi primeiramente realizado um teste in vitro, transfectando-se células humanas HEK 293 com este plasmídeo e obtendo-se uma expressão de $3,0 \mu \mathrm{g} \mathrm{mGH} / 10^{6}$ células/dia, contra $3,7 \mu \mathrm{g}$ $\mathrm{mGH} / 10^{6}$ células/dia, para o UBI-hGH-gDNA. Estes dois plasmídeos foram então

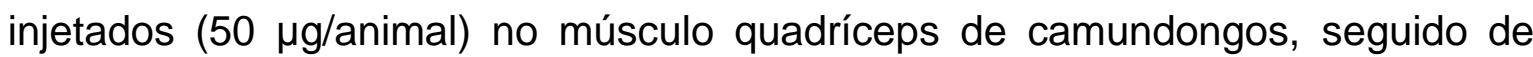
eletroporação, realizando um ensaio de 94 dias. Enquanto após 15 dias, as inclinações das curvas de variação de peso relacionadas ao $\mathrm{mGH}$, hGH e salina foram 0,130, 0,112 e 0,027 g/camundongo/dia, respectivamente, após 94 dias, as inclinações correspondentes foram 0,041, 0,028 e 0,033 g/camundongo/dia. As análises estatísticas mostraram que após 15 dias, as inclinações das duas curvas com o GH foram significativamente maiores que a inclinação do controle $(P<0,001)$, enquanto que após 94 dias, somente a inclinação da curva do $\mathrm{mGH}$ foi maior que a do controle $(\mathrm{P}<0,005)$. A porcentagem de aumento de peso nos animais tratados com o gene do $\mathrm{mGH}$, após 94 dias, foi de $34,3 \%$, enquanto que o comprimento nariz-cauda e o comprimento do fêmur, dois parâmetros que medem diretamente o crescimento longitudinal, foram de $9,5 \%$ e $26 \%$,
\end{abstract}


respectivamente, quando comparados aos valores iniciais. A interrupção do crescimento progressivo do grupo tratado com hGH não foi inesperada, considerando a óbvia reação imunogênica dos animais imunocompetentes contra o GH humano e não contra o de camundongo (título do anticorpo anti-hGH 1:100 a 1:3200). A inclinação altamente positiva do grupo controle, já observada em camundongos lit/lit mas não em lit/scid, é provavelmente devida ao ganho de peso natural desta linhagem, não suportada, contudo, por um proporcional crescimento longitudinal. Níveis circulatórios de $\mathrm{mGH}$ da ordem de $4 \mathrm{ng} / \mathrm{mL}$ foram detectados após 15 dias para o grupo tratado com $0 \mathrm{mGH}$, enquanto o grupo controle apresentou níveis em torno de $0,7 \mathrm{ng} \mathrm{mGH} / \mathrm{mL}(\mathrm{P}<0,001)$. Níveis circulatórios de mIGF-I foram também determinados nos dias 15, 45 e 94 nos animais tratados com $\mathrm{mGH}$, sempre mostrando valores 1,5-3,0 vezes maiores que o grupo controle, e valores 1,2-1,6 vezes maiores que o grupo tratado com hGH. Este modelo de tratamento homólogo pode ser considerado uma primeira abordagem e um importante suporte para futuros ensaios pré-clínicos baseados na administração de DNA plasmidial para o tratamento da deficiência de $\mathrm{GH}$ humano. 


\title{
AN HOMOLOGOUS MODEL OF GENE THERAPY BY IN VIVO ADMINISTRATION OF A PLASMID CONTAINING THE MOUSE GROWTH HORMONE GENE IN IMMUNOCOMPETENT DWARF MICE
}

\section{CLÁUDIA REGINA CECCHI}

\begin{abstract}
Sustained levels of circulating human growth hormone $(\mathrm{hGH})$ and highly significant weight increases, also found comparable to repeated hormone injections, were observed in previous works, after electrotransfer of naked plasmid DNA into the muscle of immunodeficient dwarf mice (lit/scid). In the present work an homologous animal model for $\mathrm{GH}$ gene therapy was studied by cloning the genomic sequence of mouse GH-DNA (mGH-gDNA), which substituted hGHgDNA in the plasmid that had been used in immunodeficient dwarf mice, now named UBI-mGH-gDNA and used in immunocompetent dwarf mice (lit/lit). An in vitro test was first carried out by transfecting HEK 293 human cells with this plasmid and obtaining an expression of $3.0 \mu \mathrm{g} \mathrm{mGH} / 10^{6}$ cells/day, against $3.7 \mu \mathrm{g}$ $/ 10^{6}$ cells/day obtained with UBI-hGH-gDNA. The same two plasmids DNA (50 $\mu \mathrm{g} /$ mouse) were then injected into the quadriceps muscle of lit/lit, followed by electroporation, carrying out a 94-day assay. While after 15 days the slopes of the weight variation curves related to $\mathrm{mGH}, \mathrm{hGH}$ and saline were $0.130,0.112$ and $0.027 \mathrm{~g} / \mathrm{mouse} /$ day respectively, after 94 days the corresponding slopes were $0.041,0.028$ and $0.033 \mathrm{~g} / \mathrm{mouse} /$ day. Statistical tests showed that after 15 days the slopes of both $\mathrm{GH}$ curves were significantly higher than the control $(P<0.001)$, while after 94 days only the slope of the $\mathrm{mGH}$ curve was significantly higher than the control $(\mathrm{P}<0.005)$. Weight increase for $\mathrm{mGH}$-treated mice, after 94 days, was $34.3 \%$, while nose-to-tail and femur length, both directly measuring longitudinal growth, increased $9.5 \%$ and $26.0 \%$, respectively, when compared to the initial values. The progressive growth arrest of the hGH-treated mice was not unexpected, considering the obvious immunogenic reaction of the immunocompetent animals against human and not against mouse GH (anti-hGH antibody title $1: 100$ to $1: 3200)$. The highly positive slope of the control group, already observed in lit/lit but never in lit/scid, is probably due to the natural weight
\end{abstract}



gain of this strain, not supported, however, by a proportional longitudinal growth. $\mathrm{mGH}$ circulating levels of the order of $4 \mathrm{ng} / \mathrm{mL}$ were detected after 15 days for $\mathrm{mGH}$-treated mice, while the control presented levels around $0.7 \mathrm{ng} \mathrm{mGH} / \mathrm{mL}$ $(P<0.001)$. Mouse IGF-I serum levels were also determined on day 15, 45 and 94 in mGH-treated mice, always showing 1.5-3.0 fold higher values than the control and 1.2-1.6 fold higher values than hGH-treated mice. This homologous treatment model can be considered a first approach and an important support to the preclinical testing of naked DNA administration for the treatment of human $\mathrm{GH}$ deficiency. 


\section{INTRODUÇÃO}

\subsection{Terapia gênica}

A terapia gênica pode ser definida pela introdução e expressão de genes ausentes ou defeituosos em células somáticas para tratamento de diversas doenças. Uma vez que o gene de interesse é inserido na célula, a nova informação genética utiliza a maquinaria celular do hospedeiro para expressar estes produtos gênicos. O DNA é utilizado como um agente farmacológico para induzir mudanças terapêuticas, e, desta forma, a expressão da proteína de interesse pode ser mantida por um período prolongado após a administração de uma única dose do gene (Garlick \& Fenjves, 1996).

Este tipo de terapia não se limita às possibilidades de substituir ou corrigir genes defeituosos, ou eliminar seletivamente células marcadas. Um espectro terapêutico muito mais amplo se apresenta à medida que novos sistemas são desenvolvidos para permitir a liberação de proteínas terapêuticas, tais como hormônios, citocinas, anticorpos, antígenos, ou novas proteínas recombinantes, e é a esperança de tratamento para um grande número de doenças até hoje consideradas incuráveis por métodos convencionais, das hereditárias e degenerativas às diversas formas de câncer e doenças infecciosas (Dani, 2000).

Muitos dos protocolos de terapia gênica são focados no ganho de uma função que pode alterar o fenótipo de uma célula, mas há também, ultimamente, um interesse maior em se desenvolver terapias de inibição de função, utilizando moléculas de ácido ribonucleico (RNA) (Caplen, 2004). Basicamente, pequenas moléculas de RNA são sintetizadas, a partir do seu genoma, de modo a produzir estruturas similares a "grampos", formando moléculas de RNA dupla-fita (ou duplexes de RNA, também conhecidos como micro RNA, ou miRNA), que controlam a expressão de genes celulares, a partir de um bloqueio da síntese proteica. O silenciamento pode ser obtido, com a introdução de uma pequena molécula duplex de RNA (19 a 30 pares de base) diretamente nas células em cultura; então, essas moléculas conhecidas como siRNA (small interfering RNA), complementares à sequência do gene-alvo, podem reduzir a expressão deste em 
até $80 \%$ (Menck \& Ventura, 2007). Um dos exemplos dessa aplicação, utilizando fatores de crescimento, foi descrito por Phillmann e col., (2012), que desenvolveram um miRNA para anti-VEGF (fator de crescimento endotelial vascular) e demonstraram em modelo murino, que o VEGF foi inibido por este miRNA, permitindo uma atenuação potente de VEGF in vivo.

Transferência gênica é um termo que inclui todos os procedimentos que visam a entrada de algum material genético em células-alvo. Os agentes utilizados para esta entrada do material genético nas células são conhecidos como vetores. Um vetor plasmidial é uma molécula de DNA circular purificada, construído por meio de técnicas de DNA recombinante para conter, além do gene terapêutico de interesse, sequências regulatórias, como promotores e intensificadores, para facilitar e controlar a expressão do gene (Dani, 2000). O vetor ideal possui algumas características altamente desejáveis, entre as quais podemos destacar: capacidade de acomodação de um transgene de tamanho ilimitado, baixa imunogenicidade e citotoxidade, expressão estável do transgene, direcionamento para tipos específicos de células ou tecidos, baixo custo, fácil produção e manipulação e ainda possibilidade de regular a expressão do gene exógeno no tempo e/ou na quantidade (Nardi e col., 2002).

Dentre a diversidade de doenças, é muito improvável que um único vetor seja adequado para todas as aplicações. Portanto, a variedade de vetores para terapia gênica tem aumentado constantemente e é dividida em duas categorias principais de transferência gênica: viral e não-viral (Lavigne \& Górecki, 2006).

As formas de transferência viral utilizam o vírus como veículo transportador, mais especificamente retrovírus, adenovírus ou vírus adenoassociados, destacando-se os vetores retrovirais por possuirem uma capacidade de clonagem suficiente para vários genes terapêuticos e integrarem-se ao genoma do hospedeiro com alta eficiência (Miller e col., 1993; Robbins e col., 1998) (Fig. 1). Contudo, o risco de uma mutagênese por inserção e de respostas imunes ao vetor é uma desvantagem desta modalidade de tratamento. Devido a este problema, muitos protocolos passaram a utilizar sistemas de transferência gênica não-virais, destacando-se a injeção direta de plasmídeos, denominada "naked DNA", que pode ou não ser combinada a técnicas químicas e físicas para aumentar sua eficiência (Gothelf \& Gehl, 2010). 


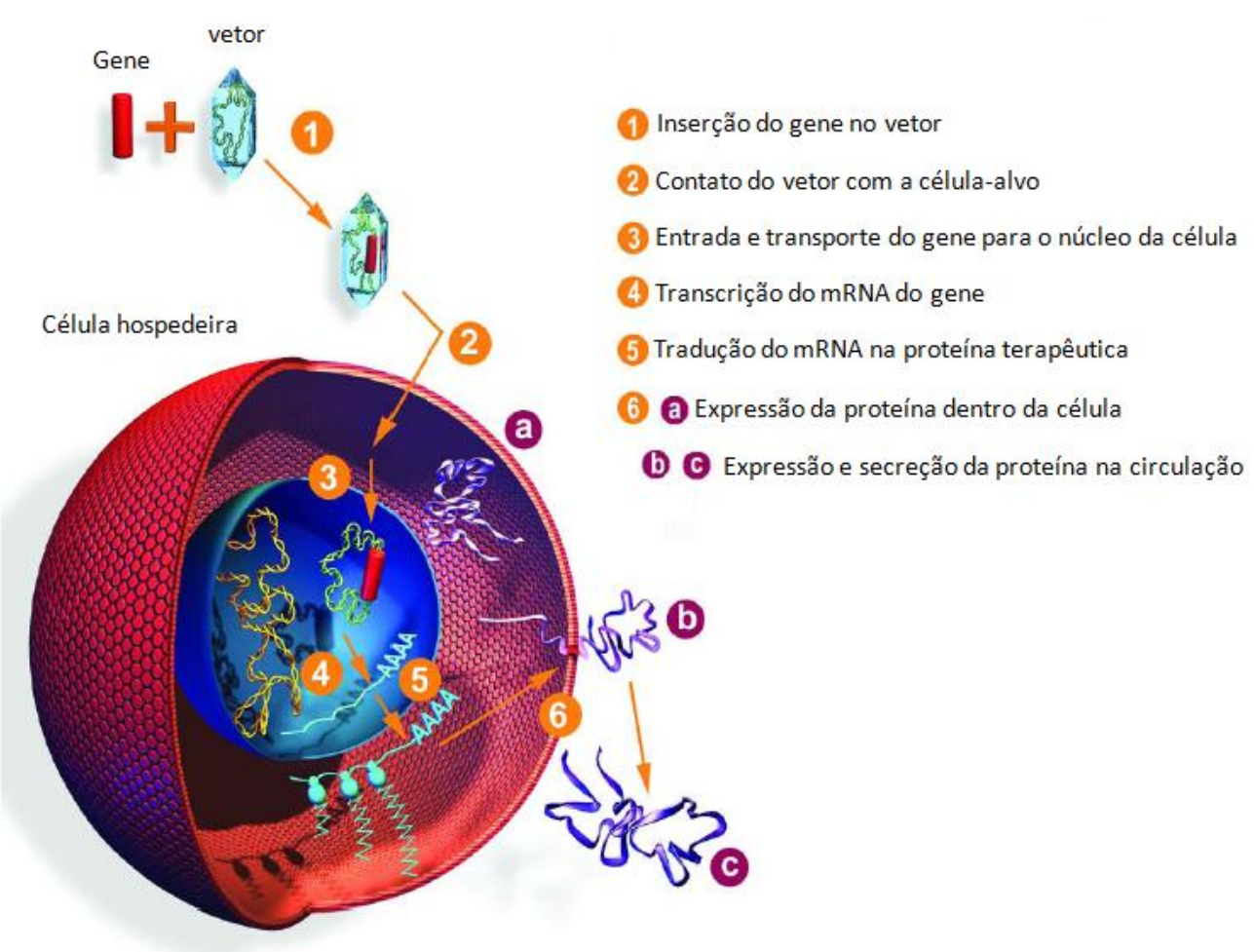

Fig.1 Forma de transferência viral. Expressão e entrega do gene terapêutico carregado por um vetor viral.

A transferência gênica não-viral pode ser utilizada para a terapia gênica $e x$ vivo e in vivo (Fig. 2), incluindo a obtenção de vacinas de DNA, e para a produção de proteínas recombinantes em células de mamíferos. Para isso, o DNA plasmidial deve ser produzido em uma forma relativamente estável e pura, e pode ser introduzido na célula por injeção direta, eletroporação, ultrassom, ou associado a complexos com lipídeos catiônicos, polímeros ou peptídeos (Gill e col., 2009). Na terapia in vivo, os genes que irão substituir a função dos seus homólogos defeituosos, são transferidos diretamente para os tecidos do animal utilizado no estudo. Na terapia ex vivo, células são removidas do animal e cultivadas em laboratório. Nessa população celular é realizada a transferência do gene de interesse e posteriormente as células são selecionadas, assim aquelas que receberam o gene são reimplantadas nos animais (Strachan \& Read, 1999). Com esta modalidade de tratamento é possível introduzir um material genético na célula-alvo, com objetivo de curar uma doença ou desacelerar sua progressão. Um dos maiores obstáculos ao sucesso desta metodologia é o desenvolvimento 
de vetores seguros e eficazes para entrega do material genético na célula (Verma \& Weitzman, 2005).

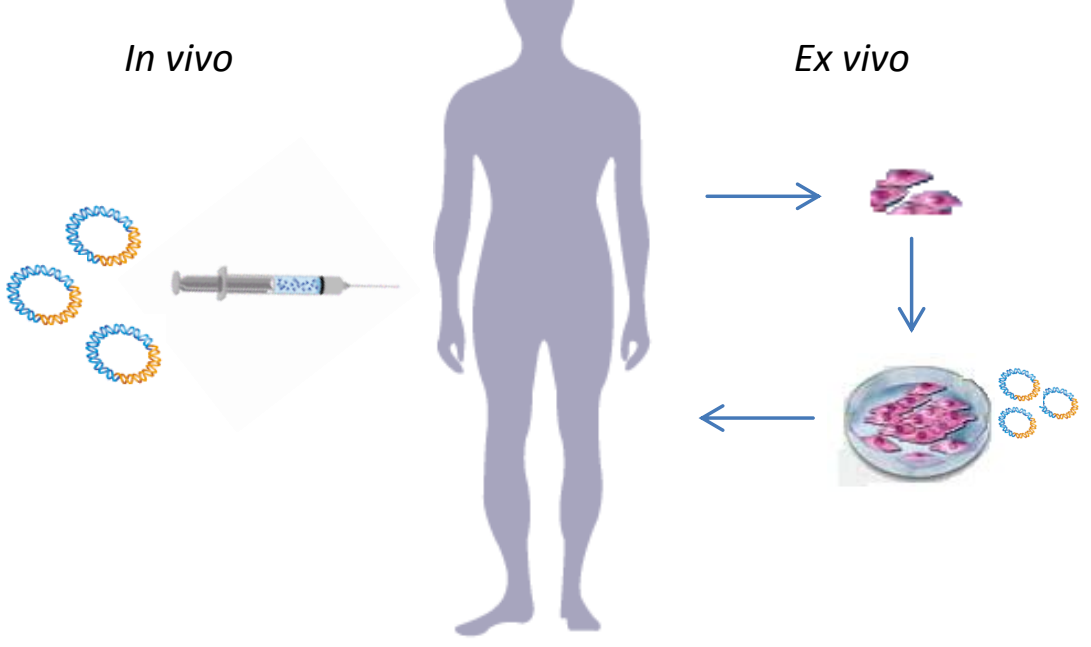

Fig.2: Esquema de terapia gênica ex vivo e in vivo. Na terapia ex vivo, as células são retiradas de um paciente, transduzidas com o vetor que carrega o gene terapêutico, selecionadas e expandidas in vitro e reintroduzidas no paciente. Já na terapia in vivo, o vetor contendo o gene de interesse é injetado diretamente no tecido-alvo do paciente.

A transferência gênica in vivo é uma estratégia promissora para o tratamento de diversas doenças, incluindo aquelas que requerem a liberação sistêmica de proteínas terapêuticas (Hojman e col., 2007).

Um dos principais métodos para entrega de material genético é a administração direta de um plasmídeo de DNA (pDNA ou naked DNA), contendo o gene terapêutico (Lavigne \& Górecki, 2006). Este método tem sido considerado simples e seguro, e o DNA pode ser transferido para as células in vivo, resultando na expressão da proteína de interesse (Liu e col., 2006). Embora o músculo seja o tecido utilizado com maior frequência, a transferência gênica também é eficiente para córnea, pulmão, fígado, rins, tumores e pele (Gothelf \& Gehl, 2010).

Métodos seguros e eficientes para entrega de DNA in vivo são necessários para o estudo funcional dos genes e para aplicações em terapia gênica. Entre os métodos não virais, o uso do campo elétrico que propicia a transfecção celular por plasmídeo de DNA é altamente utilizado como um método físico, e permite a melhora da eficiência da transfecção de tecidos in vivo (Bloquel e col., 2004). 


\subsubsection{Injeção hidrodinâmica}

Para expressão de genes que podem ser secretados no sistema circulatório, o fígado é particularmente um órgão favorecido, pelo tamanho e habilidade para secretar vários polipeptídeos (Bell e col., 2007). Um método relativamente fácil, que utiliza o fígado como superprodutor de proteína, é a injeção hidrodinâmica. Em camundongos, essa injeção requer um grande volume de injeção de DNA (aproximadamente 10\% do peso total de um camundongo), diluído em solução salina isotônica e injetado diretamente via intravenosa, através da veia caudal, em relativo curto espaço de tempo ( $<10$ segundos) (Bell e col., 2007).

A injeção hidrodinâmica de um plasmídeo simples contendo o promotor da ubiquitina humana e o gene do hGH resultou em uma expressão elevada e prolongada deste hormônio em camundongos NOD/SCID, com grandes efeitos fisiológicos da proteína: aumento no peso corpóreo, aumento nos níveis de IGF-I no soro e relativo aumento do peso dos órgãos destes animais (Dagnaes-Hansen e col., 2002).

\subsubsection{Eletrotransferência gênica}

Para aumentar a eficiência da transferência do material genético, a injeção direta do plasmídeo pode ser associada à aplicação de pulsos elétricos nas células, que levam à permeabilização transiente da membrana (eletropermeabilização ou eletroporação). Este fenômeno traz novas propriedades para a membrana: ela pode ser permeabilizada e o material genético pode ser inserido nas células. Recentemente, a eletroporação tem sido utilizada para a transferência de DNA in vivo para diversos órgãos e tecidos, e principalmente para células do músculo esquelético. Esta técnica possui muitas vantagens, como ser de fácil utilização, rápida, reprodutiva e segura (Golzio e col., 2004). A eficiência de transfecção por eletroporação pode ser otimizada por alguns fatores e parâmetros, como o tamanho e a quantidade do plasmídeo de DNA injetado e o tipo de eletrodo utilizado (Escoffre e col., 2010). A magnitude do campo elétrico 
depende do tipo de célula, tamanho, orientação, densidade, duração e números de pulsos elétricos (Fig. 3).

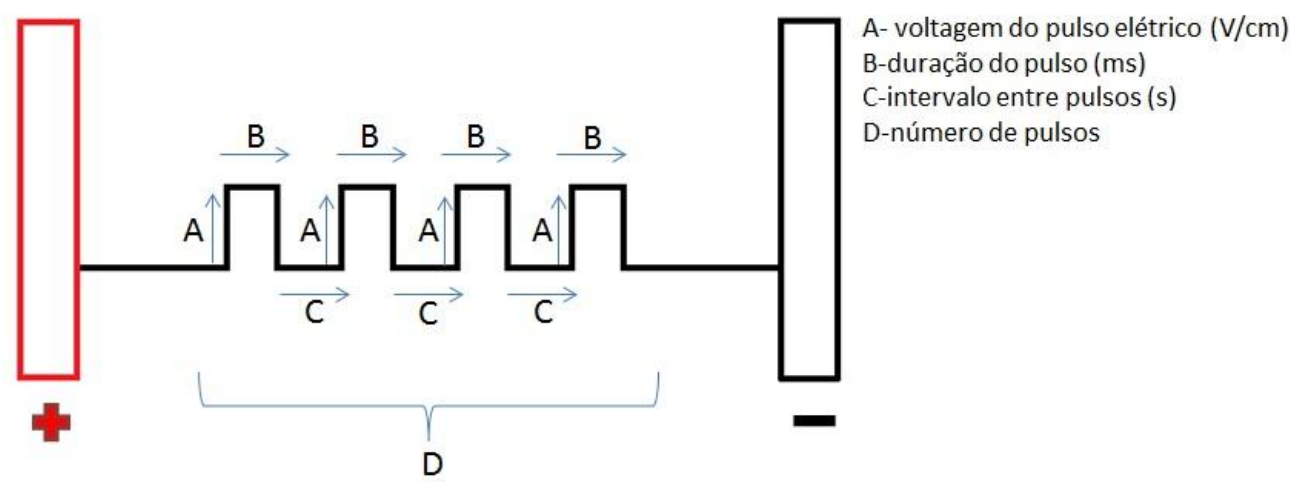

Fig. 3: Esquema da magnitude do campo elétrico durante a eletroporação, utilizando tipo de onda quadrada.

Um parâmetro-chave da eletrotransferência gênica é a intensidade do campo elétrico. Como o campo elétrico resulta a partir de uma tensão aplicada entre dois eletrodos, a configuração do eletrodo (material, tamanho, espessura e distância entre os eletrodos) controla a distribuição do campo elétrico e a eficiência da transfecção (Gehl \& Mir, 1999). A geometria e o posicionamento dos eletrodos afetam a distribuição do campo elétrico, o qual é importante para uma efetiva eletropermeabilização in vivo (Fig.4) (Miklavcic e col., 2010). Eletrodos para fins terapêuticos consistem em placas paralelas que controlam a distribuição do campo eléctrico no tecido e a permeabilização das membranas celulares. Se o campo eléctrico é muito alto, ocorre uma alteração irreversível da membrana celular, resultando em queimaduras locais e morte celular. É muito importante obter uma permeabilização transiente do tecido submetido à eletroporação, a fim de preservar a viabilidade celular. Portanto, é necessário escolher a configuração ideal dos parâmetros de eletroporação, tipo de eletrodo e o número e a intensidade do pulso para o tecido-alvo específico (Escoffre e col., 2009). 


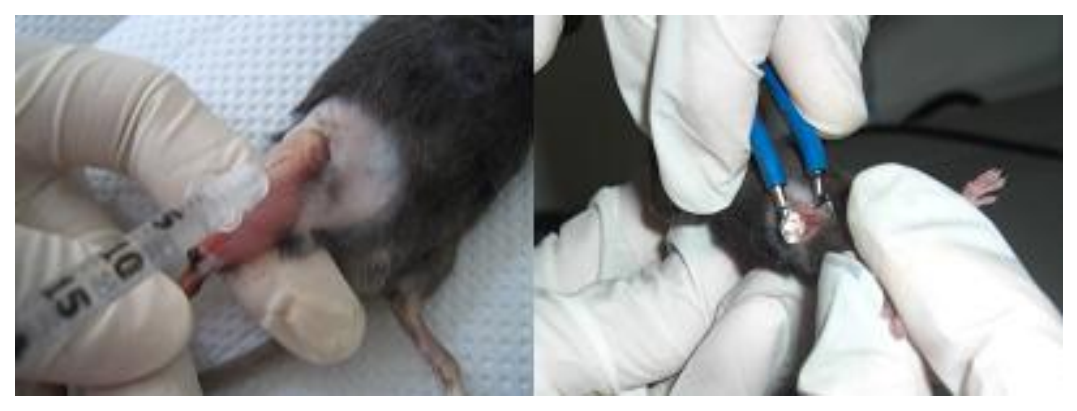

Fig. 4 Injeção direta do plasmídeo no músculo quadríceps, seguida de eletroporação. Nota-se o posicionamento dos eletrodos de forma paralela ao músculo quadríceps, onde em contato com o tecido, os pulsos elétricos são aplicados a fim de aumentar a eficiênca da entrada do DNA na célula.

O emprego desta técnica no músculo e na pele tem demonstrado resultados satisfatórios com vários genes, entre eles o da eritropoietina (Epo), do hormônio liberador de hormônio do crescimento (GHRH) e do hormônio de crescimento humano (hGH) (Rizzuto e col., 1999; Fattori e col., 2005; Prud'homme e col., 2006; Miyazaki \& Miyazaki, 2008; Brown e col., 2009; Khan e col., 2010; Oliveira e col., 2010; Higuti e col., 2012).

Particularmente, o músculo esquelético tem sido demonstrado ser o tecido mais promissor para a técnica de eletrotransferência de genes em vários contextos, como: (i) não há substituição significativa de células no músculo esquelético, de modo que os genes introduzidos não são rapidamente perdidos após a mitose; sendo assim, a expressão do transgene pode persistir por períodos relativamente longos; (ii) o músculo esquelético tem um suprimento abundante de sangue vascular, proporcionando assim um sistema eficiente para 0 transporte da proteína para a circulação (Liu e col., 2006). 


\subsection{Hormônio de crescimento}

Uma possível aplicação deste tipo de terapia seria para o tratamento da deficiência de hormônio de crescimento (DGH), a qual pode ser causada por defeitos genéticos, ou mais frequentemente por disfunção pituitária ou hipotalâmica (Dagnaes-Hansen e col., 2002). O tratamento da DGH, via administração parenteral do hormônio de crescimento humano recombinante (rechGH), apresenta vários benefícios, entre eles a disponibilidade praticamente ilimitada deste hormônio com alta pureza. A necessidade da aplicação de repetidas injeções torna, porém este processo dispendioso e inconveniente para o paciente. Uma alternativa que pode levar à correção dos defeitos clínicos é apresentada pela transferência gênica de hGH em células somáticas do paciente, tanto in vivo como ex vivo (Khamaisi e col., 2007).

O hormônio de crescimento pertence à família dos hormônios polipeptídicos estruturais, a qual é formada por uma série de moléculas regulatórias cuja função é transmitir informação específica entre células e órgãos, para o controle do crescimento, desenvolvimento, reprodução e manutenção da homeostase metabólica (Das e col., 1996).

O hormônio de crescimento é produzido e secretado especificamente pelas células somatotróficas da glândula pituitária anterior, e sua função mais importante é promover o crescimento linear, com ação sobre o metabolismo e sobre o crescimento longitudinal, estimulando a produção local e sistêmica do fator de crescimento semelhante à insulina - I (IGF-I) (Das e col., 1996; Alba e col., 2005).

O hormônio de crescimento possui diversas ações metabólicas que regulam a composição corpórea, o fluído homeostático, o metabolismo da glicose e lipídico, o metabolismo ósseo e a função cardíaca (Hartman, 2000).

A deficiência de hormônio de crescimento (DGH) é uma condição na qual a secreção do GH é ausente e o crescimento espontâneo é profundamente afetado, apresentando incidência em torno de 1:50.000 pessoas por ano (Costalonga e col., 2012). Este tipo de deficiência causa alterações na composição corpórea, caracterizada por aumento de tecido adiposo e redução da massa magra (Alba e col., 2005; Khamaisi e col., 2007). 
O tratamento com GH é permitido em algumas condições, entre elas a terapia de reposição em pacientes com DGH severa. Atualmente, existem quatro preparações principais de GH disponíveis no mercado nacional para o tratamento: Genotropin (Pharmacia), Humatrope (Lilly), Norditropin (Novo Nordisk) e Saizen (Serono). Esses produtos são obtidos por tecnologia de DNA recombinante e têm uma sequência idêntica à do GH humano (Technology Appraisal 64 -National Institute for Clinical Excellence) ${ }^{1}$. Quando esta terapia foi introduzida na prática clínica, vários estudos duplo-cegos e controlados por placebo demonstraram que a reposição de GH era capaz de promover alterações benéficas na composição corporal, na densidade mineral óssea (DMO), nos fatores de risco cardiovascular e na qualidade de vida, especialmente nos pacientes com DGH mais intensa do ponto de vista clínico e laboratorial (Zaninelli e col., 2008).

Diferentes modelos animais com DGH isolada ou resistente têm sido utilizados no estudo da ausência de GH sobre o crescimento linear e composição corpórea, e para a terapia de reposição de GH e IGF-I. Sendo que a administração de GH humano nesses modelos animais pode causar o desenvolvimento de anticorpos e a redução progressiva da efetividade do tratamento, o uso de uma forma de GH espécie-específica é recomendado (Alba e col., 2005).

\subsection{Experiência em nosso grupo}

Nosso grupo de pesquisa desenvolve uma linha de pesquisa no campo da terapia gênica para DGH, utilizando técnicas ex vivo e in vivo para expressão de hormônio de crescimento (Bellini e col., 2003; Peroni e col., 2005; Peroni e col., 2006; Peroni e col., 2008; Oliveira e col., 2010, Peroni e col., 2011; Higuti e col., 2012). Recentemente, nosso grupo desenvolveu um sistema homólogo com o gene do GH de camundongo ( $\mathrm{mGH}$ ), para terapia gênica ex vivo. Queratinócitos humanos primários transduzidos com o gene do mGH foram utilizados nestes trabalhos preliminares e apresentaram um nível de secreção in vitro relativamente

\footnotetext{
${ }^{1}$ Disponível em < http://www.nice.org.uk/nicemedia/live/11504/32665/32665.pdf > Acesso em: 19 novembro 2012
} 
alto e estável, atingindo até $11 \mu \mathrm{g} \mathrm{mGH} / 10^{6}$ células/dia. Camundongos anões imunodeficientes (lit/scid) foram implantados com enxertos organotípicos contendo estas células transduzidas e foram acompanhados durante 4 meses, apresentando um aumento de peso significativo nos primeiros 40 dias. Níveis circulatórios de $\mathrm{mGH}$ atingiram um pico de $21 \mathrm{ng} / \mathrm{mL} 1 \mathrm{~h}$ após o implante, mas estes níveis rapidamente atingiram níveis basais $(\sim 2 \mathrm{ng} / \mathrm{mL})$ (Peroni e col., 2008; Cecchi, 2008).

Com relação ao estudo de sistemas homólogos, poucos autores utilizaram o gene do mGH. Al-Hendy e col., (2005) demonstraram que o mGH secretado por mioblastos microencapsulados foi capaz de promover um efeito significativo de crescimento em camundongos Snell dwarf não tratados. Marmary e col. (1999), utilizando o mesmo modelo animal, construiram um vetor adenoviral contendo o gene do $\mathrm{mGH}$, que aumentou o peso dos animais linearmente até 30 dias após injeção no músculo quadríceps.

Mas um dos maiores problemas da terapia gênica se concentra na duração da expressão da proteína de interesse. Estudos recentes demonstraram ser possível a expressão de longa duração de um gene de interesse a partir de uma técnica não viral de injeção direta de DNA plasmidial (naked DNA), sendo que esta pode ser melhorada utilizando técnicas físicas. Nosso grupo de pesquisa começou a desenvolver protocolos baseados na administração intramuscular do plasmídeo pUC-UBI-hGH, que possui o promotor da ubiquitina e a sequência genômica do hGH, associada à técnica de eletrotransferência, em camundongos anões (lit/lit) e anões imunodeficientes (lit/scid). Com a utilização desta metodologia, a secreção de hGH foi mantida pela primeira vez por um período de 60 dias na circulação de camundongos lit/scid, com níveis de 1,5 a 3,0 ng $\mathrm{hGH} / \mathrm{mL}$. Outro resultado importante, no ensaio de longa-duração, foi a obtenção de um ganho de peso significativo nos animais que receberam o plasmídeo, de aproximadamente $30 \%$, quando comparados ao grupo controle de animais injetados com solução salina. Nesse ensaio, o grupo que recebeu DNA apresentou diferença significativa em relação ao grupo que recebeu salina, para a maioria dos órgãos e tecidos avaliados, com destaque para o crescimento do músculo quadríceps direito, no qual foi injetado o DNA, que apresentou um aumento de peso de $48 \%$, enquanto o músculo esquerdo não injetado apresentou um aumento de $31 \%$ (Oliveira e col., 2010). Este fato indica uma somatória dos 
efeitos locais (autócrinos/parácrinos) e sistêmicos (endócrinos), quanto à expressão e secreção de hGH e mIGF na circulação destes animais (Higuti e col., 2012). Neste último trabalho foi também realizada uma comparação entre a eletrotransferência muscular do gene do hGH e a administração diária de hGH recombinante, durante 28 dias, verificando-se que apesar da diferença da variação de peso corpóreo ter sido significativamente superior para o grupo tratado com a proteína recombinante no final do experimento, a inclinação das curvas entre os dois grupos tratados não apresentaram diferenças significativas, assim como o comprimento da cauda e total do corpo. 


\section{OBJETIVOS}

O objetivo principal deste trabalho foi utilizar uma nova abordagem, com a construção de um sistema homólogo de tratamento, baseado na eletrotransferência de um plasmídeo contendo o gene do hormônio de crescimento de camundongo $(\mathrm{mGH})$ em camundongos anões imunocompetentes (lit/lit). Com este modelo, espera-se reproduzir o tratamento que seria realizado clinicamente em indivíduos deficientes de $\mathrm{GH}$. Foi considerado também extremamente importante acompanhar o desenvolvimento da terapia mediante determinação do mGH e do mIGF-I circulantes. 


\subsection{Material}

\subsubsection{Equipamentos e acessórios principais}

$\checkmark$ Agitador magnético modelo 258 - FANEM (São Paulo, SP, Brasil);

$\checkmark$ Agitador rotatório tipo vortex, modelo 162 - MARCONI (São Paulo, SP, Brasil);

$\checkmark \quad$ Autoclave vertical, modelo 103 - FABBE-PRIMAR (São Paulo, SP, Brasil);

$\checkmark \quad$ Balança analítica, modelo H20T - METTLER (Zurique, Suíça);

$\checkmark \quad$ Balança analítica, modelo P1000N - METTLER (Zurique, Suíça);

$\checkmark \quad$ Balança analítica, modelo M5AS - METTLER (Zurique, Suíça);

$\checkmark \quad$ Câmara de Neubauer - BOECO (Hamburg, Alemanha);

$\checkmark \quad$ Centrífuga modelo LS-3 plus - CELM (São Paulo, Brasil);

$\checkmark \quad$ Centrífuga refrigerada, modelo 22R-BECKMAN COULTER (Brea, CA, EUA);

$\checkmark$ Centrífuga refrigerada automática, modelo Super Speed $\mathrm{RC}-2 \mathrm{~B}-$ SORVALL (Newtown, CT, EUA);

$\checkmark$ Contador gama tipo "poço", com troca automática de amostra, modelo Cobra auto-gama, eficiência aproximada para ${ }^{125}$ I de $80 \%$ - PACKARD INSTRUMENT COMPANY (Downers Grove, IL, EUA);

$\checkmark \quad$ Destilador de água, modelo 016, FABBE-PRIMAR (São Paulo, SP, Brasil);

$\checkmark \quad$ Espectrofotômetro, modelo Ultrospec 2100 pro, AMERSHAM BIOSCIENCES (Pittsburgh, PA, EUA);

$\checkmark \quad$ Estufa de cultura celular, modelo 3159 - FORMA SCIENTIFIC (Marietta, OH, EUA);

$\checkmark \quad$ Fluxo laminar classe II A/B 3, modelo 1140 - FORMA SCIENTIFIC (Marietta, $\mathrm{OH}, \mathrm{EUA})$;

$\checkmark \quad$ Freezer -20 C, modelo 0651 - PROSDÓCIMO (São Paulo, SP, Brasil);

$\checkmark \quad$ Freezer $-40^{\circ} \mathrm{C}$, modelo AB 240 - METALFRIO (São Paulo, SP, Brasil);

$\checkmark \quad$ Freezer -80ํㅡ, modelo 8425 - FORMA SCIENTIFIC (Marietta, OH, EUA);

$\checkmark \quad$ Leitor de placas de microtitulação modelo MR 400 DYNATECH (Bethesda, EUA); 
$\checkmark$ Microscópio invertido, modelo ID 03 - CARL ZEISS (Oberkochen, Alemanha);

$\checkmark \quad$ Micropipetas automáticas volume variável $10 \mu \mathrm{L}, 100 \mu \mathrm{L}, 200 \mu \mathrm{L}, 1000 \mu \mathrm{L}-$ GILSON (Middleton, EUA);

$\checkmark \quad$ Micropipeta LabMate Soft Monocanal volume variável $10 \mu \mathrm{L}, 100 \mu \mathrm{L}, 200 \mu \mathrm{L}$,

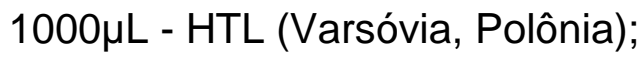

$\checkmark \quad$ Placas de microtitulação com fundo em "U” - DYNATECH (Chantilly, EUA);

$\checkmark$ Ponteiras sem filtro, volumes de 10 a $1000 \mu \mathrm{L}$ - AXYGEN (Union, EUA)

$\checkmark$ Refrigerador duplex, modelo 320 clear - BRASTEMP (São Paulo, Brasil);

$\checkmark$ Sistema de purificação de água Milli-Q plus - MILLIPORE (Bedford, MA, EUA);

$\checkmark$ Tubos de poliestireno para imunoensaios $(7,5 \times 1,2 \mathrm{~cm})$ - EMTEL (São Paulo, Brasil).

\subsubsection{Principais reagentes para biologia molecular}

$\checkmark$ Agarose - INVITROGEN (Carlsbad, CA, EUA);

$\checkmark$ Ampicilina - SIGMA (St. Louis, MO, EUA);

$\checkmark$ Bactérias competentes XL-1 blue - STRATAGENE/AGILENT TECHNOLOGIES (Santa Clara, CA, EUA);

$\checkmark$ Bactérias ultracompetentes XL-2 blue - STRATAGENE/AGILENT TECHNOLOGIES (Santa Clara, CA, EUA);

$\checkmark$ Brometo de etídio - LKB - PRODUKTER AB (Bromma, Suécia);

$\checkmark$ Enzimas de restrição - FERMENTAS (Burlington, ON, Canadá);

$\checkmark$ Enzima fosfatase alcalina (CIP) - NEW ENGLAND BIOLABS INC. (Ipswich, MA, EUA);

$\checkmark$ Enzima Herculase I/ Fusion (Agilent Technologies, La Jolla, CA, EUA);

$\checkmark$ Enzima T4 DNA Ligase HC - PROMEGA (Madison, WI, EUA);

$\checkmark$ Extrato de levedura - DIFCO (São Paulo, SP, Brasil);

$\checkmark$ Marcador de peso molecular lambda DNA / ECORI+ Hind III - FERMENTAS (Burlington, ON, Canadá);

$\checkmark$ Marcador de peso molecular 100pb Gene Ruler $^{\mathrm{TM}}$ - FERMENTAS (Burlington, ON, Canadá); 
$\checkmark$ Sistema para extração de DNA, miniprep E.Z.N.A. - OMEGA BIO-TEK (Norcross, GA, EUA);

$\checkmark$ Sistema para extração de DNA Xtra Midi/Maxi - NUCLEOBOND MACHNEREY- NAGEL (Düren, Alemanha);

$\checkmark$ Sistema para extração de gel de agarose E.Z.N.A. - OMEGA BIO-TEK (Norcross, GA, EUA);

$\checkmark$ Sistema para extração de DNA maxi-prep QIAGEN - QIAGEN (Hilden, Alemanha);

$\checkmark$ Triptona-Bacto ${ }^{\mathrm{TM}}$ Tryptone-BECTON DICKINSON (Sparks, EUA).

\subsubsection{Principais materiais e reagentes para cultura celular}

$\checkmark$ Ácido etilenodiaminotetracético (EDTA) - LABSYNTH (São Paulo, SP, Brasil);

$\checkmark$ Dimetilssulfóxido (DMSO) - MERCK (São Paulo, Brasil);

$\checkmark$ Garrafas de $75 \mathrm{~cm}^{2}$ - CORNING COSTAR CORP. (NY, EUA);

$\checkmark$ Lipofectamina - INVITROGEN (Carlsbad, CA, EUA);

$\checkmark$ Meio DMEM high glucose - INVITROGEN (Carlsbad, CA, EUA);

$\checkmark$ Penicilina-estreptomicina - INVITROGEN (Carlsbad, CA, EUA);

$\checkmark$ Pipetas de 1,2,5,10 e $25 \mathrm{ml}$ - CORNING COSTAR CORP. (NY, EUA);

$\checkmark$ Placas de 6 poços - CORNING COSTAR CORP. (NY, EUA);

$\checkmark$ Sistemas de filtração de $500 \mathrm{ml}$, porosidade de $0,22 \mu \mathrm{m}$ - CORNING COSTAR CORP. (NY, EUA);

$\checkmark$ Soro fetal bovino (SFB) HYCLONE (Logan, UT, EUA);

$\checkmark$ Tripsina - INVITROGEN (Carlsbad, CA, EUA);

$\checkmark$ Tubos para centrífuga de 15 e $50 \mathrm{ml}$ - CORNING COSTAR CORP. (NY, EUA). 


\subsubsection{Materiais utilizados na administração direta de DNA plasmidial seguida de eletroporação}

$\checkmark$ Eletrodos do tipo placa (um par) de platina pura de 5,5 x 2,0 x 3,0 mm não invasivos HERAEUS VECTRA DO BRASIL (São Paulo, SP, Brasil);

$\checkmark$ Eletroporador de tecidos biológicos, construído in house (São Paulo, SP, Brasil);

$\checkmark$ Eletroporador Cliniporator IGEA (Carpi,MO, Itália);

$\checkmark$ Eletroporador BTX - MEC-830 (Holliston, MA, EUA);

$\checkmark$ Fio de sutura Caajara - CAAJARA (Cotia, SP, Brasil);

$\checkmark$ Gel eletrocondutor Flexor - FLEXOR (Sertãozinho, SP, Brasil);

$\checkmark$ Hialuronidase - Hyalozima 2.000 UTR - APSEN (São Paulo, SP, Brasil);

$\checkmark$ Isofluorano 3,75\% - Forene ${ }^{\circledR}$ - Abbott Scandinavia AB (Solna, Suécia);

$\checkmark$ Lâminas Chrome platinum BIC - BIC (Manaus, AM, Brasil);

$\checkmark$ Paquímetro digital - Mitutoyo Sul Americana Ltda. (Suzano, SP, Brasil);

$\checkmark$ Quetamina - Cetamin - SYNTEC (Hortolândia, SP, Brasil);

$\checkmark$ Seringas BD Ultra - Fine II (U-100- 29G) - BECTON DICKINSON (Franklin Lakes, NJ, EUA);

$\checkmark$ Seringas descartáveis de $1 \mathrm{~mL}$ - INJEX (Ourinhos, SP, Brasil);

$\checkmark$ Xilazina - Xilazin - SYNTEC (Hortolândia, SP, Brasil).

\subsubsection{Preparações padrão, antissoros e reagentes para} radioimunoensaio e determinação de anticorpos

$\checkmark$ Anticorpo policlonal anti-hGH, NIDDK - anti hGH-2, fornecido pelo Dr. A.F. Parlow - NATIONAL HORMONE AND PITUITARY PROGRAM (NHPP, Torrance, CA, EUA);

$\checkmark$ Azida sódica - SIGMA (St. Louis, MO, EUA);

$\checkmark$ Controles de qualidade para imunoensaios baseados em sangue humano, Lyphochek I Immunoassay Plus Control (níveis 1, 2 e 3) - BIORADINVITROGEN (Carlsbad, CA, EUA); 
$\checkmark$ Cloramina T p.a. - MERCK (São Paulo, SP, Brasil);

$\checkmark$ Fosfato de sódio bibásico p.a - MERCK (São Paulo, SP, Brasil);

$\checkmark$ Fosfato de sódio monobásico p.a - MERCK (São Paulo, Brasil);

$\checkmark$ Metabissulfito de sódio - CARLO ERBA (São Paulo, SP, Brasil);

$\checkmark \mathrm{Na}^{125}$ I comercial, livre de carreadores e oxidantes, com atividade específica de 11.100 - 22.200 MBq/ml (300 - $600 \mathrm{mCi} / \mathrm{mL})$ - NORDION EUROPE S.A. (Fleurus, Bélgica);

$\checkmark$ Polietilenoglicol - PEG 6000 - MERCK (São Paulo, SP, Brasil);

$\checkmark$ Preparação de hGH recombinante altamente purificada para iodinação IPEN- CNEN/SP (São Paulo, SP, Brasil) (Ribela e col., 1993; Oliveira e col., 1999);

$\checkmark$ Resinas cromatográficas Sephadex G100 - GE HEALTHCARE BIOSCIENCES (Piscataway, NJ, EUA);

$\checkmark$ Segundo anticorpo anti-lgG de coelho preparado em carneiro - IPENCNEN/SP (São Paulo, SP, Brasil);

$\checkmark$ Soro albumina bovina (BSA), RIA grade (fração V) - SIGMA (St. Louis, MO, EUA);

$\checkmark$ Soro de coelho normal - INVITROGEN (Carlsbad, CA, EUA);

$\checkmark$ Soro humano (coleta voluntária de sangue de indivíduo saudável);

$\checkmark$ Tween-20 - SIGMA (St. Louis, MO, EUA). 


\subsection{Plasmídeos}

- pCMV-hGH gDNA e pCMV-hGH-cDNA: contêm o promotor do citomegalovírus (CMV) e o gene do $\mathrm{GH}$ humano $(\mathrm{hGH})$. Derivam dos plasmídeos comerciais pcDNA 3.1(+) e pcDNA 3.1(-), da Invitrogen (Carlsbad, CA, EUA), os quais foram modificados com a inserção da sequência genômica (gDNA) ou complementar (cDNA) do gene do hGH (Oliveira, 2010). Estes plasmídeos foram transformados em bactérias competentes E.coli $\mathrm{DH} 5 \alpha$, amplificados e purificados utilizando o sistema comercial de maxi-prep da QIAGEN.

- pUBI-hGH-gDNA: possui o promotor da ubiquitina $C$ e a sequência genômica do hGH, foi cedido pelo Dr. T. G. Jensen (Departmento de Biomedicina, Universidade de Aarhus, Dinamarca), e tem sido utilizado por nosso grupo de pesquisa (Oliveira e col., 2010; Higuti e col., 2012). Este plasmídeo também foi transformado em bactérias competentes E.coli DH5a, amplificado e purificado utilizando o mesmo sistema mencionado acima.

- pUBI-mGH-gDNA: foi construído utilizando o cassete de expressão do plasmídeo pUBI-hGH-gDNA, com a retirada do gene do hGH para inserção da sequência genômica do GH de camundongo (gDNA). Foi realizada a reação de digestão do plasmídeo pUBI-hGH-gDNA, com as enzimas de restrição Bam $\mathrm{HI}$ e Eco Rl, para extrair o gene do hGH. O vetor foi então purificado do gel de agarose para receber mGH-gDNA. A sequência genômica do $\mathrm{mGH}$ foi inserida no programa de bioinformática vector-NTI (Invitrogen, Carslbad, CA, EUA), contendo todos os dados do novo plasmídeo. A sequência do mGH genômico foi obtida do banco de dados, Gen Bank (NM_008117.2). O primer de iniciação (F-forward) foi desenhado após o sinal TATA (1739-1743 pb) e antes do START códon (1830 pb). O primer reverso (R-reverse) foi desenhado após o STOP códon, na região 3217 pb. Cada primer continha uma razão de ligação de 50\% A-T e 50\% G-C. Os primers sintetizados foram:

mGH Bam HI (F): 5'- AAAGGATCCAGCATCCTAGAGTCCAGAT-3' mGH ECO RI (R): 5'-AAAGAATTCGGCTTCCAGGAACAAGATTG-3' 
Os primers foram desenvolvidos e comercializados pela empresa EUROFINS DNA (Ebersberg, Alemanha), para uso em reação em cadeia de polimerase (PCR). Para a reação de amplificação do gene, foi utilizado como template, o DNA proveniente de uma biblioteca de DNA genômico de camundongo, extraído e cedido pela Dra. Maria Jacobsen, do Departamento de Biomedicina da Universidade de Aarhus na Dinamarca. A reação de PCR foi realizada utilizando a enzima Herculase // e seguindo o seguinte protocolo:

$95^{\circ}$ C - 5 minutos

$\left.\begin{array}{l}95^{\circ} \mathrm{C}-30 \text { segundos } \\ 57^{\circ} \mathrm{C}-30 \text { segundos } \\ 72^{\circ} \mathrm{C}-2 \text { minutos }\end{array}\right\} 40$ ciclos

$72^{\circ} \mathrm{C}-7$ minutos

$10^{\circ} \mathrm{C}-\infty$

O produto final do PCR foi purificado em gel de agarose com o sistema comercial E.Z.N.A. e utilizado para ligação no vetor UBI, após desfosforilação com a enzima CIP. A reação de ligação foi realizada overnight a $16^{\circ} \mathrm{C}$ com a enzima T4 DNA ligase $\mathrm{HC}$ e após a ligação, foi realizada a transformação em células ultracompetentes XL-2 Blue. As bactérias cresceram em placas de ágar LB contendo o antibiótico ampicilina e foi realizado um teste de triagem dos clones recombinantes por PCR, a partir dos primers sintetizados: $F$ (forward) TCCTGCTTCAAGAAGGACCT e R (reverse) - ATTCAGGCTGCGCAACTGTT e, entre as regiões de $5176 \mathrm{pb}-5563$ pb do vetor pUBI-mGH-gDNA (Fig.10). Dentre 12 clones isolados, 11 apresentaram a banda de aproximadamente $400 \mathrm{pb}$ relacionada à região amplificada, presente na região terminal do gene. O DNA plasmidial destes 11 clones foi obtido por um sistema comercial de minipreparação e a digestão dos produtos mediante $E c o \mathrm{Rl}$ e Bam $\mathrm{Hl}$, para confirmar o tamanho esperado para o mGH genômico, de 1,6 Kb. A confirmação da orientação do gene no plasmídeo foi realizada por teste de restrição, com a enzima Fsp I, e por sequenciamento de DNA. A quantidade do plasmídeo foi amplificada para os experimentos subsequentes, utilizando o sistema comercial de midi-prep da Nucleobond. 


\subsection{Transfecção em células HEK 293}

Para o teste de expressão in vitro, foi realizada a transfecção transiente de células HEK 293 utilizando o sistema de lipossomos PLUS ${ }^{T M}$ Reagent da Invitrogen, de acordo com as instruções do fabricante. As células foram semeadas em placas de 6 poços $\left(5 \times 10^{4}\right.$ células/poço), cultivadas a $37{ }^{\circ} \mathrm{C}$ in $5 \%$ $\mathrm{CO}_{2}$ e transfectadas com o plasmídeo de interesse pUBI-mGH-gDNA, e também com o vetor pUBI-hGH-gDNA, como controle positivo de expressão. O plasmídeo pUBI-hEPO, que possui a sequência genômica da eritropoietina humana, foi utilizado como controle negativo. Todas as transfecções foram feitas em triplicata.

O cultivo das células HEK 293 foi realizado em meio DMEM sem adição de soro. $\mathrm{O}$ meio de cultura foi coletado após 48 horas, e as concentrações do mGH e hGH foram determinadas por ensaios imunoespecíficos.

\subsection{Animais}

\subsubsection{Linhagens utilizadas}

Foram utilizados camundongos normais das linhagens NMRI e C57BL/6J, adquiridos da empresa Taconic (Dinamarca), mantidos no Biotério da Universidade de Aarhus (Aarhus, Dinamarca), e camundongos da linhagem C57BL/6J-GHRHR ${ }^{\mathrm{LIT} /+}$ (lit/lit), e heterozigotos lit/+, adquiridos da empresa THE JACKSON LABORATORY (Bar Harbor, ME, EUA), e mantidos no Biotério do IPEN - CNEN/SP (São Paulo, SP, Brasil). Os animais tinham idade entre 60 e 90 dias, machos e fêmeas. A utilização dos animais das linhagens normais foi autorizada pelo Comitê Dinamarquês de Experimentação Animal, e a utilização da linhagem lit/lit foi autorizada pelo Comitê de Ética em Pesquisa com Animais (CEPA) - Projeto $n^{\circ}$ 11/CEPA-IPEN/SP, de 27 de outubro de 2006. 


\subsubsection{Condições de manutenção}

Os animais foram mantidos em gaiolas plásticas (mini-isoladores), dentro de estantes ventiladas, a temperatura de $22 \pm 2^{\circ} \mathrm{C}$, sob condições livres de patógenos, com ciclo circadiano de 12:12 h de claro/escuro, alimentados com ração padrão e água ad libidum, durante os experimentos. Em tempos préestabelecidos foi realizada coleta de sangue via plexo retro-orbital e, ao final dos experimentos, os animais foram sacrificados por deslocamento cervical.

\subsection{Injeção hidrodinâmica de plasmídeos}

Após a confirmação da análise de expressão in vitro, o plasmídeo pUBImGH-gDNA foi injetado via hidrodinâmica em camundongos NMRI e C57BL6, de acordo com protocolo estabelecido (Dagnaes-Hansen e col., 2002; Sondergaard e col., 2003). Esta injeção consiste em aplicar um grande volume de DNA (10\% do peso total em um curto espaço de tempo). Os animais foram preparados para receber a injeção sob uma lâmpada infravermelha para dilatação dos vasos sanguíneos e permaneceram sob efeito do anestésico isofluorano $3,75 \%$ até ausência de reflexo. A veia caudal foi comprimida com o auxílio de um elástico e $75 \mu \mathrm{g}$ de DNA diluído em solução de Ringer ( $\mathrm{NaCl} 147 \mathrm{mM}, \mathrm{KCl} 4 \mathrm{mM}, \mathrm{CaCl}_{2} 1,13$ $\mathrm{mM}$ ) foram injetados em menos de 10 segundos. Após a injeção, o peso de todos os animais foi monitorado semanalmente e o sangue foi coletado para dosagem de $\mathrm{mGH}$ em diferentes intervalos de tempo. $\mathrm{O}$ mesmo procedimento foi também realizado com o plasmídeo pUBI-hGH-gDNA, utilizado como controle positivo de expressão.

\subsection{Injeção de plasmídeos associada à eletroporação}

Os experimentos relacionados à eletroporação foram realizados utilizando três modelos de eletroporadores, dois destes disponíveis no Departamento de Fisiologia da Universidade de Aarhus, o Cliniporator, da empresa IGEA e o MEC- 
830, da BTX. Para os experimentos realizados no Brasil, utilizamos um eletroporador construído "in house", no Instituto de Pesquisas Energéticas e Nucleares - IPEN.

\subsubsection{Injeção intramuscular}

Os animais foram anestesiados e o pêlo da região do músculo a ser injetado foi removido. Para os camundongos normais, foi aplicada uma injeção de $10 \mu \mathrm{g}$ de DNA no músculo tibial anterior e, para o protocolo de injeção nos animais deficientes de $\mathrm{GH}$, foram aplicados $50 \mu \mathrm{g}$ de DNA no músculo quadríceps, diluído em solução salina (PBS), em um volume final de $20 \mu \mathrm{L}$ e de $50 \mu \mathrm{L}$ respectivamente, utilizando seringas de calibre 29G (U-100 insulin - BD microfine). $O$ grupo controle recebeu apenas a injeção de solução salina.

A seguir, o músculo foi eletroporado, seguindo as condições estabelecidas para combinação de pulsos de alta e baixa voltagem (Hojman e col., 2011) para os camundongos normais, com 1 pulso de $800 \mathrm{~V} / \mathrm{cm}$ e 1 pulso de $100 \mathrm{~V} / \mathrm{cm}$, com duração de 400 milisegundos e um intervalo de 1 segundo entre o pulso alto e o baixo. Os animais da linhagem lit/lit receberam 8 pulsos de $150 \mathrm{~V} / \mathrm{cm}$, com duração de 20 milisegundos e intervalo de 0,5 segundos entre os pulsos (Oliveira e col., 2010).

\subsection{Bioensaio}

Antes do ensaio de administração do DNA plasmidial, foi realizado um préensaio, durante 10 dias consecutivos, onde os camundongos lit/lit foram pesados diariamente e, aqueles que apresentaram uma variação de $\pm 3 \%$ do peso durante este período, foram eliminados (Bellini \& Bartolini, 1993; Bellini e col., 1998).

No bioensaio, os camundongos lit/lit foram anestesiados com uma mistura de quetamina e xilazina, via intraperitoneal. Os pêlos da região do músculo quadríceps direito foram removidos e esse músculo foi exposto para injeção do DNA ou salina. Os animais foram divididos em 3 grupos: o primeiro foi injetado com o plasmídeo pUBI-mGH-gDNA ( $n=8)$, o segundo com o plasmídeo pUBI- 
hGH-gDNA ( $n=7)$ e o terceiro com solução salina estéril $(n=6)$. Foram aplicados $50 \mu \mathrm{g}$ de plasmídeo diluídos em um volume de $50 \mu \mathrm{L}$ de solução salina estéril. Logo após a injeção, o músculo injetado foi submetido à aplicação de 8 pulsos de $150 \mathrm{~V} / \mathrm{cm}$, com duração de 20 milisegundos, e um intervalo de 0,5 segundo entre cada pulso (Oliveira e col., 2010).

O peso destes animais foi monitorado diariamente até 0 15ำ dia e depois semanalmente até o 94ํ dia, para o cálculo da variação de peso e da porcentagem de aumento de peso. O sangue foi coletado nos dias 15, 45 e 94 para dosagem de mIGF-I, de mGH ou hGH e determinação da formação de anticorpos anti-hGH. Foi monitorado o comprimento total (do nariz à cauda), comprimento da cauda e do fêmur, com a utilização de um paquímetro digital. Os animais foram pesados também nos dias seguintes às coletas, a fim de verificar a queda de peso, após a retirada de aproximadamente $250 \mu \mathrm{L}$ de sangue.

\subsection{Dosagem de hGH, mGH e mIGF-I}

Todas as amostras de sangue coletadas durante os experimentos foram processadas, e o soro foi armazenado em freezer $-20^{\circ} \mathrm{C}$ para dosagem de $\mathrm{hGH}$, mGH, mIGF-I ou presença de anticorpos.

Durante o estágio na Dinamarca, a dosagem de $\mathrm{hGH}$ foi realizada em colaboração com a equipe do Departamento de Endocrinologia liderado pelo Dr. Jan Frystyk, no Hospital Universitário da Universidade de Aarhus. Todas as amostras foram dosadas em duplicata, e a determinação do hGH foi realizada pelo método de imunofluorimetria (Delphia, Wallac Oy, Turku, Finland).

Para a determinação de hGH em nosso laboratório, foi utilizado um radioimunoensaio específico para este hormônio (Bellini e col., 2003). Os reagentes utilizados são provenientes do NHPP (preparação padrão e anticorpo anti-hGH) e do IPEN (preparação de rec-hGH para iodinação), e o ensaio apresenta sensibilidade de $0,1 \mathrm{ng} \mathrm{hGH/mL}$. Como controle de qualidade para estes ensaios, foram utilizadas preparações comerciais de controle de qualidade (Lyphochek I Immunoassay Plus Control) com diferentes concentrações deste hormônio. 
A dosagem de $\mathrm{mGH}$ foi realizada em duplicata utilizando o sistema comercial ELISA da Milipore (St. Charles, MO, EUA), com sensibilidade de 0,07 ng/mL. Para dosagem de mIGF-I foi utilizado o sistema Quantikine mouse/rat IGFI immunoassay da R\&D System (Minneapolis, MN, EUA) e as amostras foram também dosadas em duplicata.

\subsection{Determinação de anticorpos anti-hGH no soro dos camundongos}

As amostras de soro foram analisadas para verificar a presença de anticorpos anti-hGH, utilizando um método de precipitação com PEG (DagnaesHansen e col., 2002; Glezer e col., 2006). Foram incubados por $16 \mathrm{~h}$ a $4^{\circ} \mathrm{C}, 100 \mu \mathrm{L}$ de soro diluído 1:50 adicionados de 50 $\mu \mathrm{L}$ de ${ }^{125} \mathrm{I}-\mathrm{hGH}$ (Ribela e col., 1993; Oliveira e col., 1999), correspondentes a $25.000 \mathrm{cpm}$ (contagem por minuto) ou a aproximadamente $0,2 \mathrm{ng}$ da preparação de ${ }^{125} \mathrm{I} \mathrm{hGH} /$ tubo, em tampão fosfato de sódio 0,01M, pH7,4,0,1\% BSA, 0,01\% tween-20. A separação foi realizada pela adição de $150 \mu \mathrm{L}$ de PEG 6000 25\% e 22,5 $\mu \mathrm{L} /$ tubo de soro humano, preparado

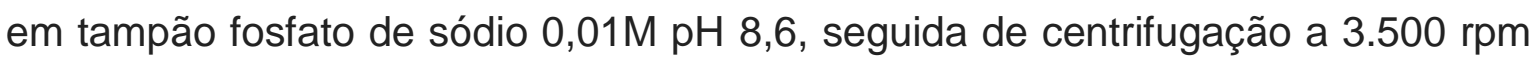
por 30 min. Foi realizada uma lavagem do precipitado com $300 \mu \mathrm{L}$ de PEG 12,5\% e repetida a centrifugação. Foi utilizado como controle positivo, nas diluições de 1:15.000 a 1:1.440.000, o anticorpo policlonal anti-hGH produzido em coelho mediante um protocolo específico de imunização, obtido do Dr. A.F. Parlow (NHPP). Foi considerado que havia a presença de quantidades significativas de anticorpos anti-hGH quando a radioatividade precipitada (Bound) das amostras foi maior que a média \pm 2 D.P. das contagens obtidas nas amostras de controle negativo (soro dos camundongos injetados com solução salina relativa a cada dia da determinação), calculando também as porcentagens de ligação específica. Os soros dos animais injetados com o pUC-UBI-hGH que apresentaram a maior e menor porcentagem de ligação foram também titulados utilizando diluições variando de 1:50 a 1:1.000.000. 


\subsection{Análise estatística}

As comparações entre todos os parâmetros de crescimento foram realizadas por meio do teste t de Student, considerando não significativo $P>0,05$. Os dados foram reportados como valores médios \pm desvio-padrão (DP).

Para valores médios \pm D.P. dos ensaios de peso e secreção da proteína de interesse, foi utilizado o programa estatístico Graphpad Prism (versão 5.0, GraphPad Software Inc., La Jolla, CA, EUA), e a significância realizada pelo teste 2way ANOVA. 


\subsection{Administração de plasmídeos contendo o gene do hGH seguida por eletroporação}

Esta primeira etapa do trabalho foi realizada durante um estágio na Dinamarca, com a finalidade de aprender as técnicas de injeção e eletroporação realizadas pelo grupo de pesquisa especializado em eletroporação do músculo, liderado pela Dra. Hanne Gissel, do Departamento de Eletrofisiologia da Universidade de Aarhus, onde havia apenas a disponibilidade de camundongos normais, e de outros tipos de eletroporadores e eletrodos, portanto, os parâmetros de eletroporação precisaram ser repadronizados nas condições deles, utilizando plasmídeos contendo o gene do hGH.

Foram utilizados diferentes vetores com promotor UBI ou CMV, contendo a sequência genômica de DNA do hormônio de crescimento humano (hGH-gDNA) ou complementar (hGH-cDNA), para injeção no músculo tibialis cranialis em camundongos normais da linhagem NRMI, seguida de eletroporação. O grupo controle foi injetado com solução salina (PBS). Os músculos (não expostos) foram eletroporados utilizando o equipamento Cliniporator e o protocolo préestabelecido, como descrito nos Materiais e Métodos. Os animais foram pesados e o sangue coletado em diferentes tempos para quantificação do hGH no soro. 


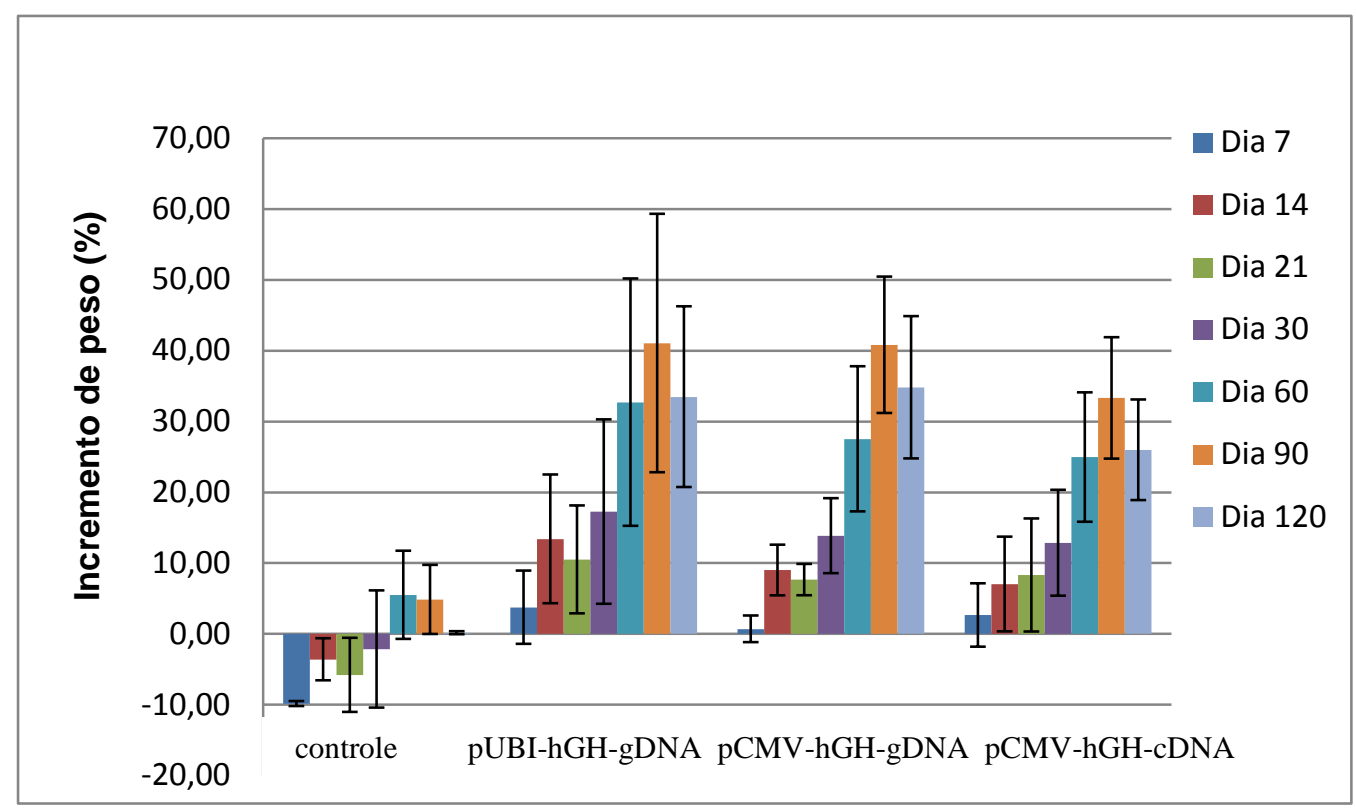

Fig. 5: Porcentagem de aumento de peso de camundongos normais NMRI, após injeção intramuscular de diferentes vetores, seguida de eletroporação. Foram utilizados $10 \mu \mathrm{g}$ de cada plasmídeo, contendo diferentes promotores (UBI ou CMV) e as sequências do hGH-gDNA e hGH-cDNA ( $\mathrm{n}=4$ animais/grupo).

Como já observado em trabalhos anteriores (Oliveira e col., 2010; Higuti e col., 2012), o plasmídeo hGH-gDNA foi capaz de proporcionar um aumento de peso quando injetado no músculo de camundongos anões imunodeficientes por até 60 dias. Na Fig. 5, podemos observar que o mesmo plasmídeo administrado em camundongos normais, proporcionou uma porcentagem máxima de aumento de peso de $41,1 \% \pm 18,2 \%$, após 90 dias da injeção, enquanto o grupo controle permaneceu sem crescimento considerável (4,9\% $\pm 4,9 \%)$. A utilização de diferentes vetores com promotor UBI ou CMV e com o cDNA ou gDNA do hGH não demonstrou diferença significativa no ganho de peso para injeções intramusculares seguida de eletrotransferência, indicando assim que o vetor com o promotor UBI é tão eficiente quanto o promotor CMV, para este modelo de terapia gênica.

A dosagem de hGH no soro dos animais mostrou, porém, um baixo nível de secreção deste hormônio, entre 0,15 - 0,40 ng de $\mathrm{hGH} / \mathrm{mL}$, apresentando níveis quase indetectáveis após 30 dias (Fig. 6). 


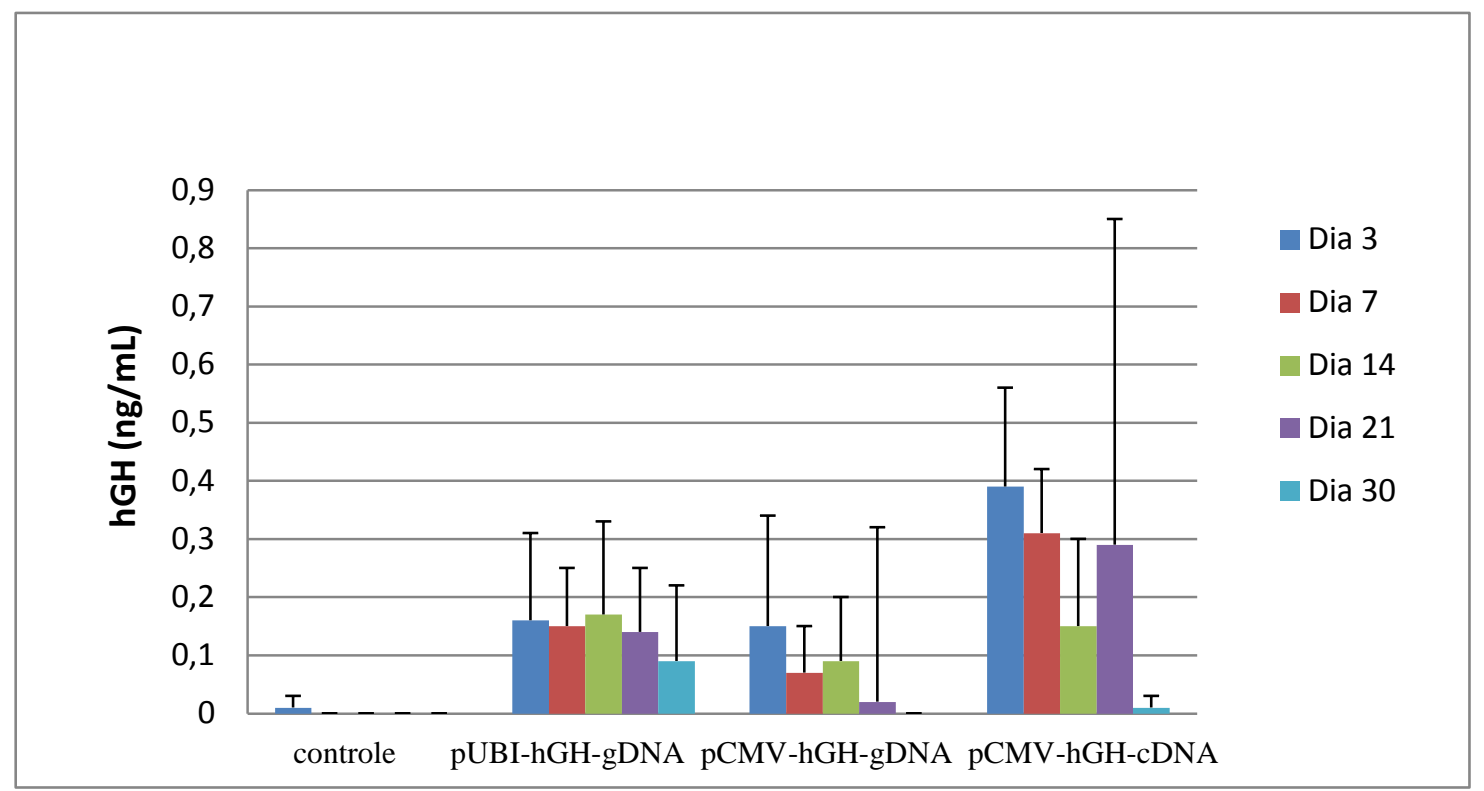

Fig. 6: Níveis de hGH na circulação de camundongos normais NRMI, após injeção de diferentes plasmídeos contendo o promotor UBI ou CMV, e as sequências do DNA genômico ou complementar do hGH. ( $\mathrm{n}=4$ animais/grupo).

Durante esta etapa do trabalho foi também realizado um teste de eficiência de eletrotransferência, comparando os dois modelos de eletroporadores disponíveis, o Cliniporator e o BTX.

Foi realizada a injeção intramuscular dos pCMV-hGH-gDNA e pCMV-hGHcDNA em camundongos NMRI, e cada grupo foi eletroporado com um equipamento. Não houve diferença no aumento de peso dos animais injetados com os diferentes equipamentos e vetores (Fig. 7), mostrando que os dois aparelhos funcionam de forma equivalente para as injeções intramusculares. $O$ grupo controle obteve aumento de peso inferior a $10 \%$.

Dessa maneira, foi verificado que a injeção intramuscular destes diferentes plasmídeos foi capaz de proporcionar um aumento de peso significativo nos camundongos normais NMRI.

Com a finalidade de determinar a concentração da proteína circulante e o aumento de peso de animais imunocompetentes deficientes de hormônio de crescimento (lit/lit), a partir de injeções de DNA via intramuscular e intradérmica, o próximo passo seria a construção de um sistema homólogo de expressão de $\mathrm{GH}$, que pudesse ser aplicado em nosso modelo animal e para isso foi necessária a construção de um vetor baseado no gene do $\mathrm{mGH}$, como descrito a seguir. 
Resolveu-se clonar a sequência genômia de DNA de $\mathrm{mGH}$, sendo que a sequência complementar não tinha proporcionado resultados satisfatórios.

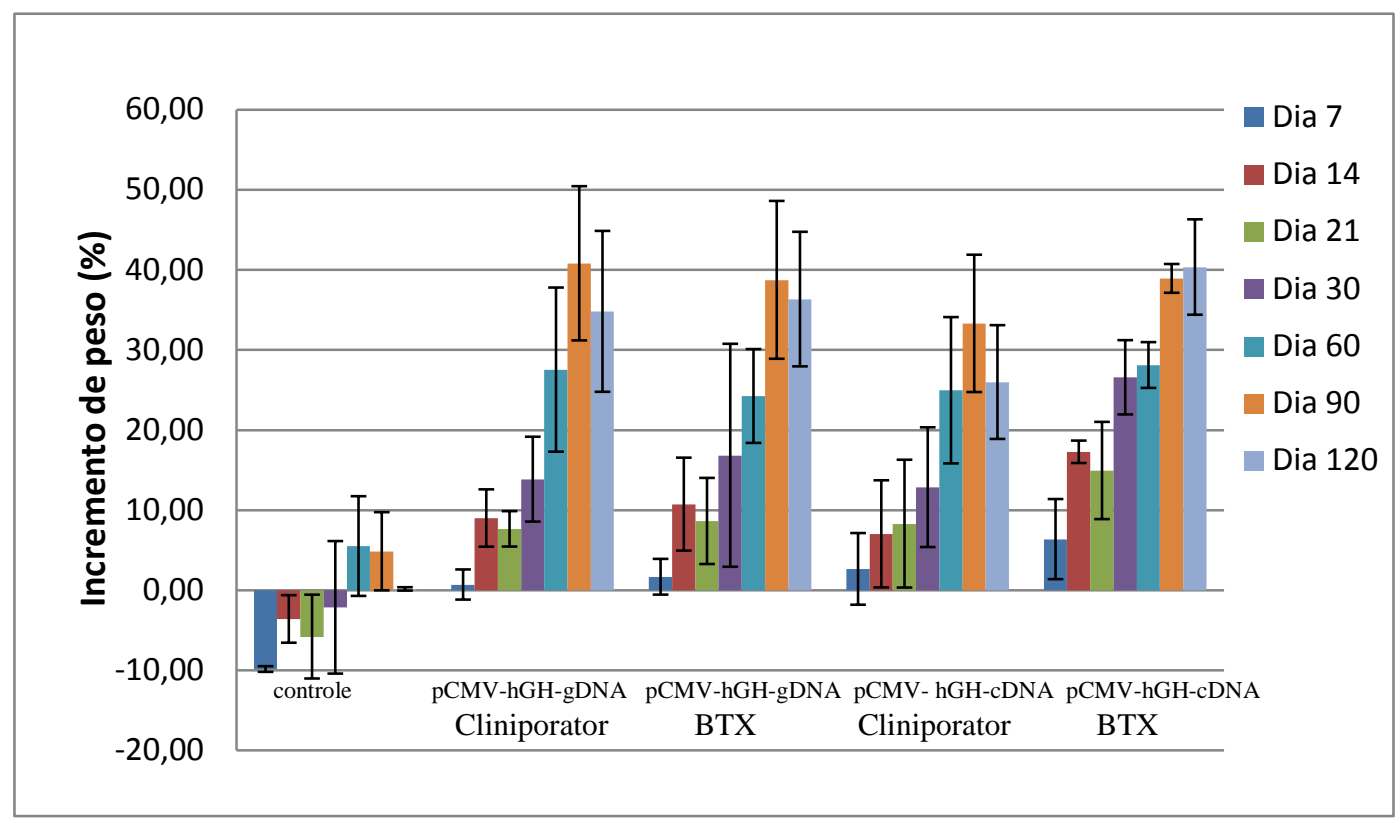

Fig. 7: Comparação entre a eficiência de dois modelos de eletroporadores: Cliniporator e BTX. Camundongos NMRI receberam o mesmo tratamento de injeção intramuscular de DNA, seguida de eletroporação. O grupo controle recebeu solução de Ringer. ( $n=4$ animais/grupo).

\subsection{Construção do vetor pUBI-mGH-gDNA}

Após as etapas iniciais de clonagem do inserto mGH-gDNA no vetor pUCUBI, descritas nos Materiais e Métodos, as bactérias competentes foram transformadas com o produto da reação de ligação e foi realizado um teste de triagem do DNA plasmidial relativo aos clones obtidos por PCR. Na análise do gel após a reação (Fig. 8), verifica-se que 11, dos 12 clones analisados, apresentaram o fragmento de 400 pb relacionado à região amplificada, mostrando a ligação do inserto ao vetor. 


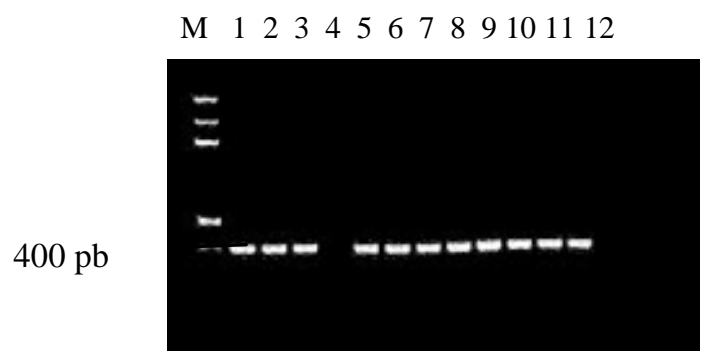

Fig. 8: Gel de agarose dos clones transformados com o plasmídeo pUBI-mGH-gDNA e submetidos à PCR. (1-12) Foram analisados 12 clones e 11 apresentaram a região amplificada de aproximadamente 400 pb correspondente a um fragmento do gene do mGH genômico, como descrito nos Materiais e Métodos, (M) Marcador de peso molecular de $100 \mathrm{pb}$.

A seguir, o DNA plasmidial destas 11 amostras foi digerido com as enzimas de restrição Bam $\mathrm{Hl}$ e Eco $R \mathrm{l}$, e analisado em gel de agarose 1\%, no qual foi verificado que todos os clones possuíam o tamanho correto do inserto (a banda correspondente ao mGH genômico, de 1,6 kb) e do vetor (Fig. 9). A última amostra foi aplicada no gel como um controle positivo e refere-se ao vetor pUBIhGH-gDNA, também digerido com Bam $\mathrm{HI}$ e Eco $\mathrm{Rl}$, que libera o fragmento correspondente ao hGH genômico de 2,2 kb.

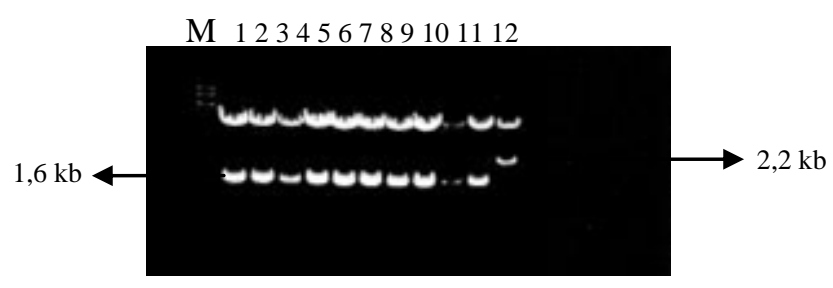

Fig. 9: (1-11) DNA plasmidial de clones contendo o pUBI-mGH-gDNA, com a presença da banda correspondente à sequência genômica do mGH de 1,6 Kb. (12) DNA plasmidial de um clone contendo o pUBI-hGH-gDNA, onde se verifica a banda do hGH genômico de 2,2 kb. Todas as amostras foram digeridas com Bam HI e Eco RI . (M) Marcador de $1 \mathrm{~kb}$.

O clone número 5 foi escolhido para ser amplificado e utilizado nos experimentos seguintes. Foi realizada uma análise de restrição, digerindo o DNA 
deste clone com a enzima Fsp I, confirmando a orientação correta do inserto no vetor, pela obtenção de bandas de 3136, 1236, 1024 e 434 pb (Fig. 10).

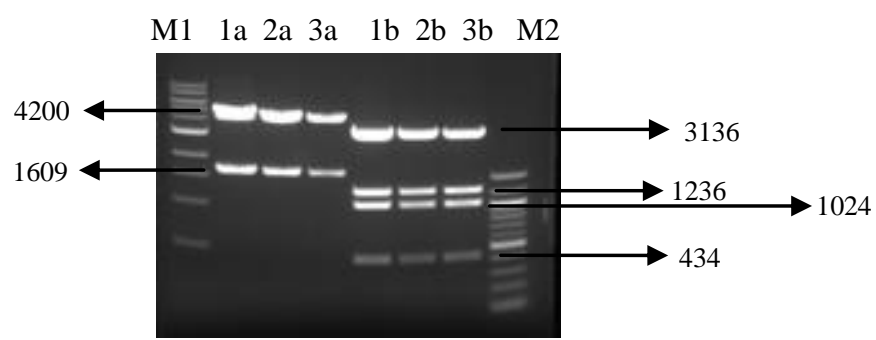

Fig. 10: Análise de restrição do plasmídeo pUBI-mGH-gDNA. 1-3a - Digestão de 3 diferentes preparações de DNA com as enzimas Bam HI e Eco RI. 1-3b- Digestão das mesmas preparações com a enzima Fsp I. M1- marcador de 1 Kb; M2- marcador de 100 $\mathrm{pb}$.

Após todas as etapas confirmarem a clonagem do mGH-gDNA no vetor puC-UBI, foi realizado o sequenciamento do novo plasmídeo. O esquema do vetor obtido é apresentado na Fig. 11.

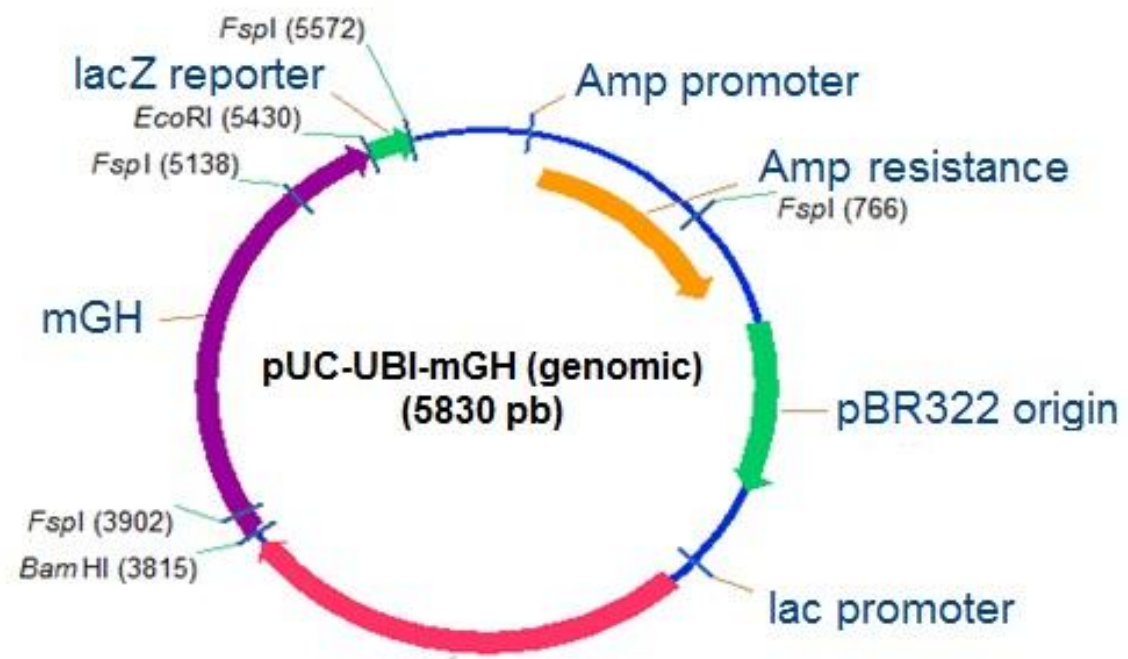

UBI C promoter

Fig. 11: Esquema do vetor pUBI-mGH-gDNA, mostrando o gene do mGH-gDNA clonado entre os sítios Bam HI e Eco Rl, sob controle do promotor da Ubiquitina - C, os sítios de restrição para a enzima $F s p$ I, e outros elementos do vetor bacteriano de origem. 


\subsection{Expressão de $\mathrm{mGH}$ in vitro}

Células HEK 293 foram transfectadas com os vetores pUBI-mGH-gDNA e pUBI-hGH-gDNA, e para o controle negativo foi utilizado o plasmídeo pUBI-hEPO gDNA.

Dois dias após a transfecção, o meio das células foi coletado, o mGH foi dosado por ELISA e o hGH por RIA (Tabela 1). Os resultados de expressão de mGH mostraram que o gene deste hormônio é funcionante in vitro, pois foi obtida uma expressão da ordem de $3 \mu \mathrm{g} \mathrm{mGH} / 10^{6}$ células/dia, comparável àquela observada para o hGH.

Tabela 1: Nível de expressão de mGH ou de hGH em células HEK 293 transfectadas com os plasmídeos UBI-mGH-gDNA, UBI-hGH-gDNA ou UBIhEPO-DNA

\begin{tabular}{|c|c|c|c|}
\hline Plasmídeo & $\begin{array}{c}\text { Número de } \\
\text { células }\end{array}$ & $\begin{array}{c}\mathbf{n g ~ G H / m L} \\
\mathbf{( n = 3 )}\end{array}$ & $\begin{array}{c}\mathbf{n g} \mathbf{G H} / \mathbf{1 0} \mathbf{6}^{\mathbf{c}} \text { céls/dia } \\
\mathbf{( n = 3 )}\end{array}$ \\
\hline UBI-mGH-gDNA & $5 \times 10^{4}$ & $149,4 \pm 6,1$ & $2986,0 \pm 122,2$ \\
\hline UBI-hGH-gDNA & $5 \times 10^{4}$ & $186,7 \pm 28,9$ & $3733,3 \pm 577,4$ \\
\hline UBI-hEPO-gDNA & $5 \times 10^{4}$ & n.d. & - \\
\hline
\end{tabular}

n.d. = não detectável

\subsection{Injeção hidrodinâmica}

Para analisar a secreção de $\mathrm{mGH}$ in vivo, foi realizada uma injeção hidrodinâmica de DNA pela veia caudal. Foram injetados os plasmídeos pUBImGH-gDNA e o pUBI-hGH-gDNA, como controle positivo. O grupo controle negativo recebeu injeção de solução de Ringer. $O$ peso dos camundongos normais NRMI foi monitorado durante 120 dias, e foi observado um incremento de peso de até $44,4 \% \pm 20,7 \%$ nos animais que receberam o plasmídeo pUBI-mGH- 
gDNA, resultado bem próximo do controle positivo, que apresentou 49,7\% \pm $15,6 \%$, enquanto o peso do controle negativo aumentou apenas $17,7 \% \pm 3,5 \%$, como está mostrado na Fig. 12.

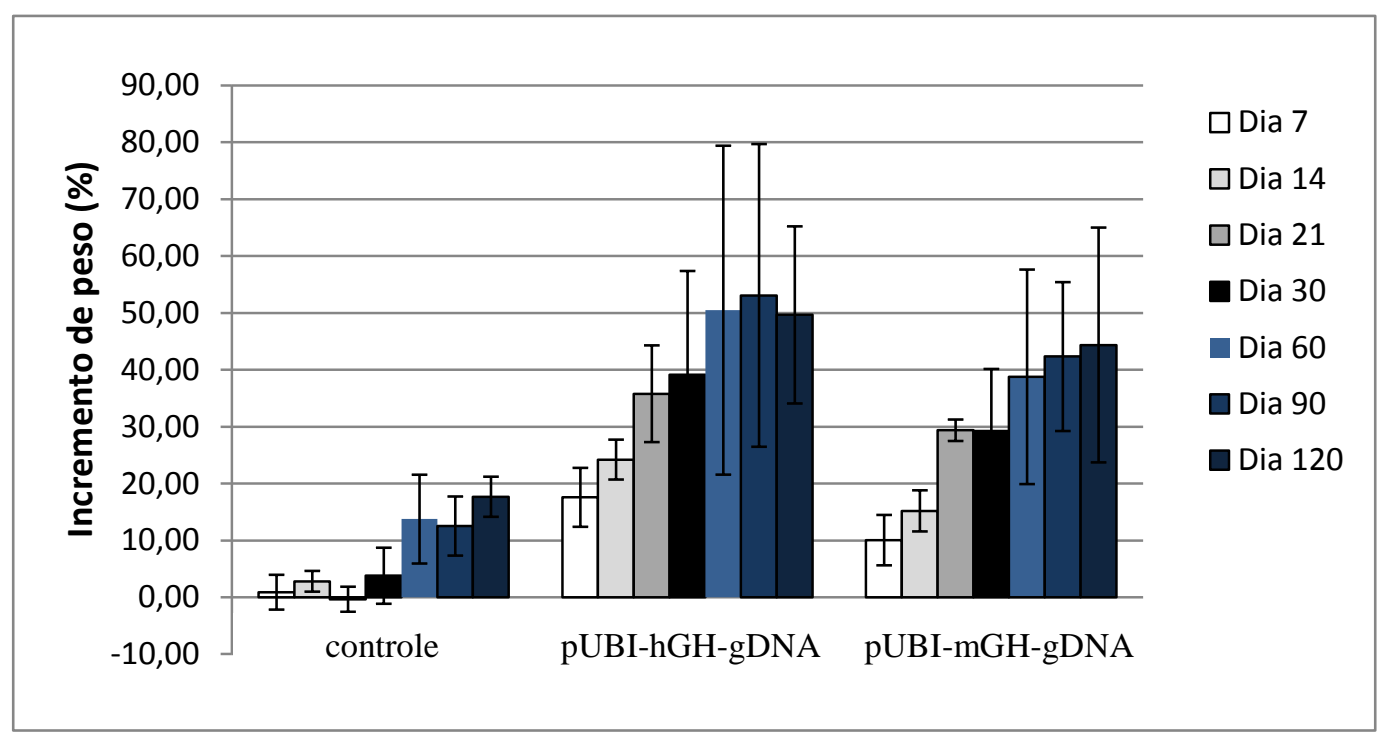

Fig. 12: Porcentagem de incremento de peso após injeção hidrodinâmica de $75 \mu \mathrm{g}$ de DNA plasmidial em camundongos normais da linhagem NRMI. Foram utilizados os plasmídeos pUBI-mGH-gDNA e o pUBI-hGH-gDNA, utilizado como controle positivo. Para o controle negativo, foi injetada solução de Ringer. ( $n=4$ animais/grupo)

Foi ainda realizado outro teste de injeção, via hidrodinâmica, utilizando camundongos da linhagem C57BL6, para confirmar a expressão de mGH em um segundo modelo animal de camundongos normais, e o nível de secreção da proteína de interesse.

Na Fig. 13, podemos observar que os camundongos da linhagem C57BL6 que receberam o plasmídeo contendo o gene do $\mathrm{mGH}$, apresentaram um incremento de peso maior do que aqueles que receberam o gene do hGH por via hidrodinâmica. $\mathrm{O}$ grupo que recebeu o gene do $\mathrm{mGH}$ apresentou um ganho de peso de $66,2 \% \pm 12,1 \%$, após apenas 30 dias da injeção, enquanto o grupo que recebeu o gene do hGH apresentou um ganho de 47,5\% $\pm 18,1 \%$. Este resultado nos leva à conclusão de que camundongos da linhagem C57BL6 respondem melhor à administração do gene homólogo (mGH), quando comparados a camundongos da linhagem NRMI. 


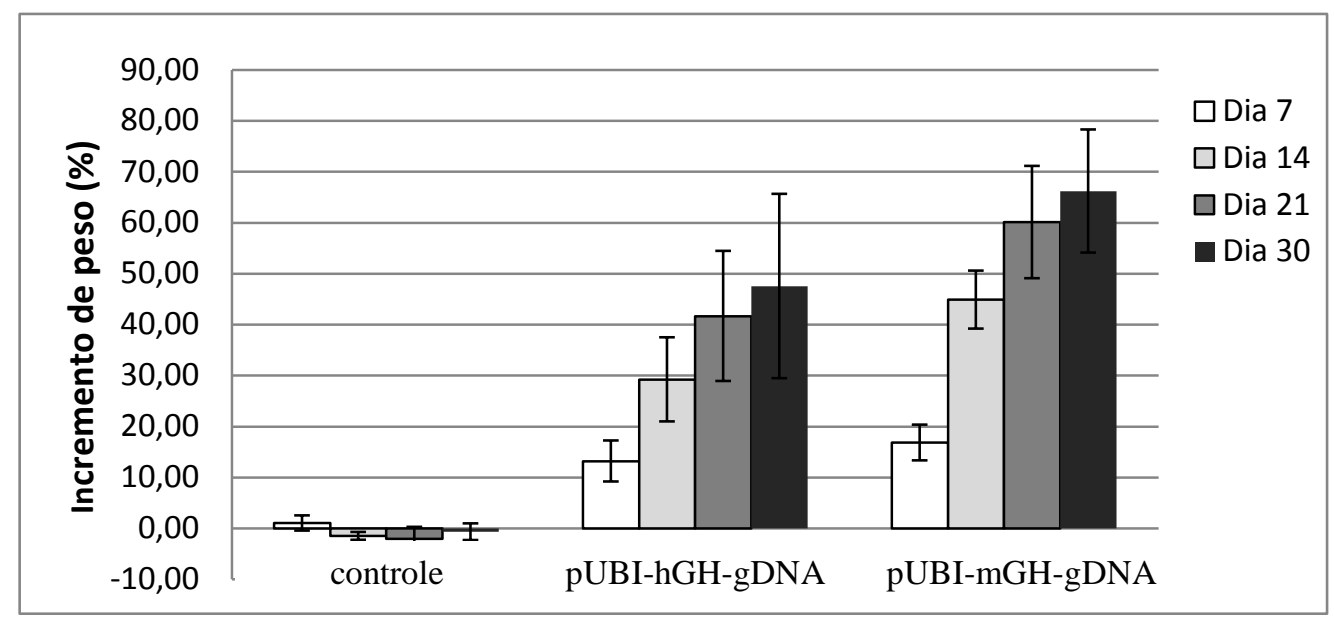

Fig. 13: Porcentagem de incremento de peso após injeção hidrodinâmica dos plasmídeos pUBI-mGH-gDNA e pUBI-hGH-gDNA, em camundongos normais da linhagem C57BL6. Para o controle negativo foi injetada solução de Ringer. ( $n=4$ animais/grupo).

A quantificação de $\mathrm{mGH}$ no soro dos animais que receberam o plasmídeo UBI-mGH-gDNA foi realizada por ELISA e a presença deste hormônio foi confirmada com níveis significativos $(\mathrm{P}<0,0001)$ e sustentáveis de até $69,7 \mathrm{ng} / \mathrm{mL}$ detectados até 120 dias após a injeção do plasmídeo via hidrodinâmica (Fig. 14).

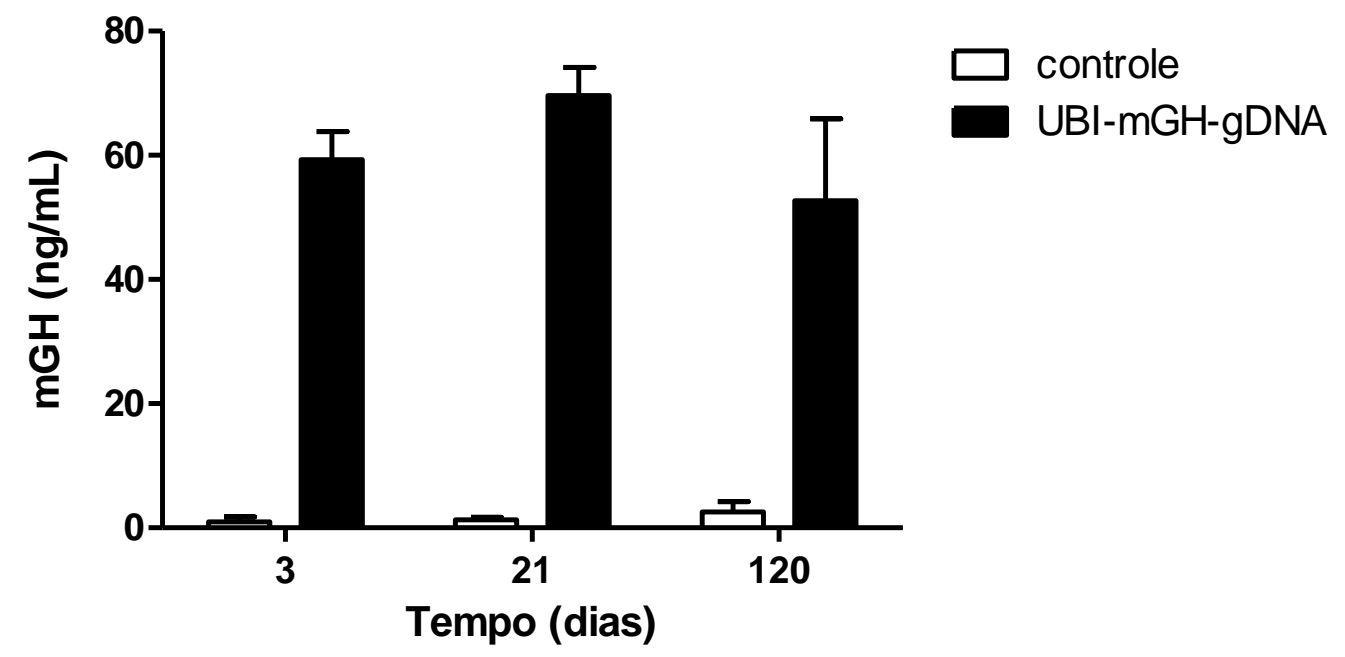

Fig.14: Níveis de mGH no soro de camundongos C57BL6 injetados via hidrodinâmica com o plasmídeo recém construído, pUBI-mGH-gDNA, 3, 21 e 120 dias após a injeção ( $\mathrm{n}=3$ animais/grupo). 


\subsection{Bioensaio associado à eletrotransferência e dosagem de mIGF-I}

\section{e $\mathrm{mGH}$}

Foi realizado um ensaio de longa duração para avaliar a resposta de crescimento de camundongos lit/lit após administração dos plasmídeos pUBImGH-gDNA e pUBI-hGH-gDNA ou de salina, no músculo quadríceps exposto dos animais, seguida de eletroporação (Fig. 15).

Observou-se uma queda de peso não significativa durante os primeiros dias após a cirurgia, como já verificado em experimentos anteriores. O grupo que recebeu o plasmídeo contendo o gene do $\mathrm{mGH}$ apresentou uma variação de peso significativa $(P<0,05)$ em relação ao peso inicial, a partir do $10^{\circ}$ dia (barra pontilhada, Fig. 15), enquanto o grupo que recebeu o gene do hGH apresentou uma variação significativa $(P<0,05)$ somente após o 14ํ dia, em uma comparação realizada entre os 3 grupos ( $\mathrm{mGH}$, hGH e salina) que receberam a injeção. Após 15 dias da administração, as inclinações das curvas de variação de peso foram de 0,$130 ; 0,112$ e 0,027 g/camundongo/dia, enquanto após 94 dias, as inclinações foram de 0,$041 ; 0,028$ e $0,033 \mathrm{~g} /$ camundongo/dia para as curvas com o $\mathrm{mGH}$, hGH e salina, respectivamente. Os valores das inclinações das curvas com GH foram significativamente maiores que a da curva com salina $(P<0,001)$ após 15 dias.

Neste ensaio, a porcentagem de aumento de peso no $30^{\circ}$ dia foi de $16,8 \%$ $\pm 5,4 \%$ para o grupo pUBI-mGH-gDNA, $8,5 \% \pm 5,3 \%$ para o grupo pUBI-hGHgDNA e $7,0 \% \pm 1,1 \%$ para o grupo salina. A partir do $30^{\circ}$ dia, observamos um aumento na variação de peso do grupo que recebeu salina, o qual apresentou um aumento significativo em relação ao tempo 0 , no $37^{\circ}$ dia, o que nos leva à conclusão de que o aumento de peso dos grupos que receberam DNA após o $30^{\circ}$ dia, foi influenciado por um crescimento dos animais em todos os grupos. Nos $16^{\circ}$ e $46^{\circ}$ dias houve uma queda da variação de peso, a qual é devida à coleta de sangue dos animais nos dias anteriores a estas pesagens. Ao final do experimento de 94 dias, as significâncias das inclinações das curvas com mGH e hGH foram de $\mathrm{P}<0,005$ e $\mathrm{P}<0,025$ em relação a da curva controle, ressaltando-se porém que nesta fase o crescimento dos animais que receberam salina foi maior que o dos animais tratados com hGH, provavelmente por causa de uma reação imunogênica ao hormônio heterólogo. 


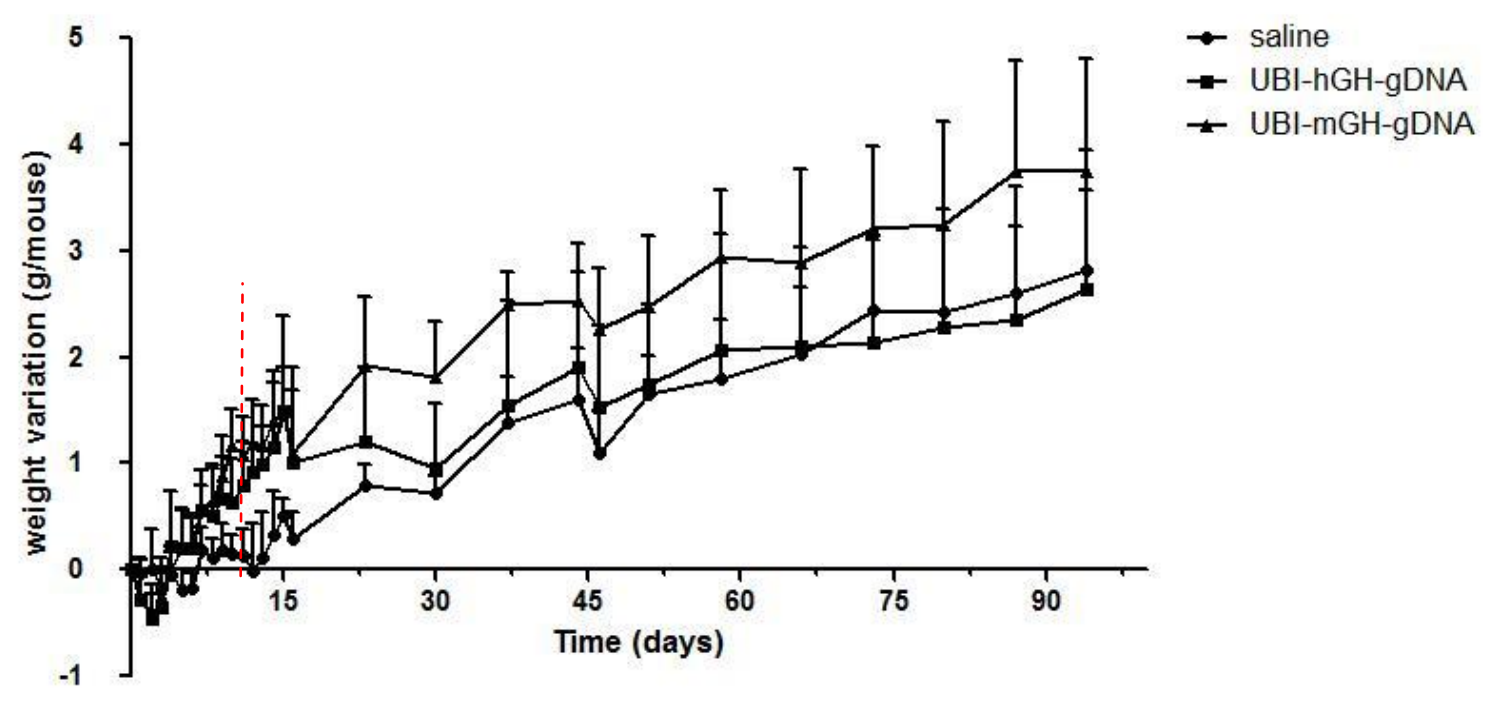

Fig. 15: Variação de peso de camundongos lit/lit após injeção intramuscular de $50 \mu \mathrm{g}$ do

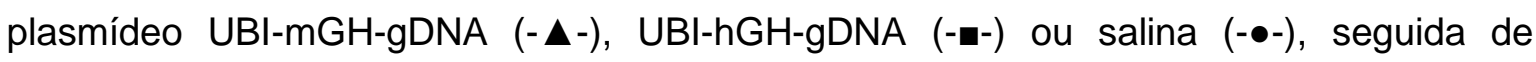
eletrotransferência. (pUBI-mGH - n= 8; pUBI-hGH-gDNA - n=7, salina - n=6).

A concentração de mIGF-I secretada após a administração dos plasmídeos

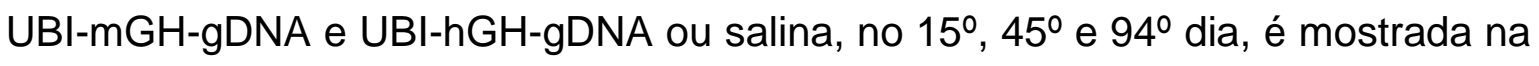
Tabela 2. No $15^{\circ}$ dia é possível observar que os níveis de mIGF-I no soro dos animais que receberam os plasmídeos foram significativamente maiores em relação ao grupo controle. O grupo pUBI-mGH-gDNA apresentou uma concentração de $93,1 \pm 20,1 \mathrm{ng} / \mathrm{mL}$, aparentemente superior a de 59,7 $\pm 26,8$ ng/mL, para o grupo pUBI-hGH-gDNA, enquanto a concentração de mIGF-I para o grupo salina foi de apenas $31,3 \pm 6,9 \mathrm{ng} / \mathrm{mL}$. No final do experimento, os níveis de mIGF-I do grupo que recebeu o gene do $\mathrm{mGH}$ foram menores $(43,6 \pm 7,7$ $\mathrm{ng} / \mathrm{mL})$, mas ainda significativamente maiores $(\mathrm{P}<0,001)$ que o do grupo salina $(28,3 \pm 2,8 \mathrm{ng} / \mathrm{mL})$. 
Tabela 2: Concentração de mIGF-I no soro de camundongos lit/lit após 15, 45 e 94 dias da administração intramuscular de $50 \mu \mathrm{g}$ do plasmídeo UBI-mGH-gDNA (mGH-gDNA), UBI-hGH-gDNA (hGH-gDNA) ou salina, seguida de eletroporação

\begin{tabular}{|c|c|c|c|c|}
\hline Grupo de animal & $\mathbf{n}$ & $\begin{array}{c}\text { mIGF-I } \\
(\mathrm{ng} / \mathrm{mL}) \pm \text { D.P. }\end{array}$ & $\begin{array}{l}\text { C.V. } \\
(\%)\end{array}$ & $\begin{array}{l}\text { Significância } \\
\text { estatística }^{*_{1}}\end{array}$ \\
\hline \multicolumn{5}{|l|}{ Lit/lit (0 dias) } \\
\hline não tratado & 4 & $29,0 \pm 16,9$ & 58,3 & - \\
\hline \multicolumn{5}{|l|}{ Lit/lit (15 dias) } \\
\hline salina & 6 & $31,3 \pm 6,9$ & 22,0 & - \\
\hline mGH-gDNA & 8 & $93,1 \pm 20,1$ & 21,6 & $P<0,001$ \\
\hline hGH-gDNA & 7 & $59,7 \pm 26,8$ & 44,9 & $P<0,01$ \\
\hline \multicolumn{5}{|l|}{ Lit/lit (45 dias) } \\
\hline salina & 6 & $30,8 \pm 5,3$ & 17,2 & - \\
\hline mGH-gDNA & 8 & $48,2 \pm 17,1$ & 35,5 & n.s. \\
\hline hGH-gDNA & 7 & $39,4 \pm 8,4$ & 21,3 & n.s. \\
\hline \multicolumn{5}{|l|}{ Lit/lit (94 dias) } \\
\hline salina & 6 & $28,3 \pm 2,8$ & 9,9 & - \\
\hline mGH-gDNA & 8 & $43,6 \pm 7,7$ & 17,7 & $P<0,001$ \\
\hline hGH-gDNA & 7 & $31,9 \pm 5,1$ & 16,0 & n.s. \\
\hline
\end{tabular}

C.V., coeficiente de variação; ${ }^{* 1}$ Significância em relação ao grupo salina de mesmo tempo de tratamento; n.s., não significativo $(P>0,05)$

Os níveis de $\mathrm{mGH}$ no soro dos camundongos lit/lit foram determinados pelo sistema ELISA da Millipore (Tabela 3). Após 15 dias de tratamento, foram obtidos $\sim 4 \mathrm{ng} \mathrm{mGH} / \mathrm{ml}$ no soro dos camundongos que receberam o $\mathrm{mGH}$-gDNA, que são aproximadamente 6 vezes $(P<0,001)$ mais elevados que os níveis observados nos animais injetados com salina. Ressaltamos que o soro dos camundongos injetados com o hGH-gDNA foi também analisado por imunoensaio específico para o $\mathrm{mGH}$, com a finalidade de observar a ausência de reação cruzada. Os 
níveis de hGH desses animais deverão ser determinados por RIA, mesmo já tendo conhecimento que os mesmos variaram de 2-6,3 $\mathrm{ng} / \mathrm{mL}$ em um estudo similar de 32 dias (Oliveira e col., 2010).

Tabela 3: Concentração de mGH no soro de camundongos lit/lit após 15, 45 e 94 dias da administração intramuscular de $50 \mu \mathrm{g}$ do plasmídeo UBI-mGH-gDNA (mGH-gDNA), UBI-hGH-gDNA (hGH-gDNA) ou salina, seguida de eletroporação

\begin{tabular}{|c|c|c|c|c|}
\hline Grupo de animal & $\mathbf{n}$ & $\begin{array}{c}\mathrm{mGH} \\
(\mathrm{ng} / \mathrm{mL}) \pm \text { D.P. }\end{array}$ & $\begin{array}{l}\text { C.V. } \\
(\%)\end{array}$ & $\begin{array}{l}\text { Significância } \\
\text { estatística }^{*_{1}}\end{array}$ \\
\hline Lit/lit não tratado & 4 & $0,21 \pm 0,06$ & 28,6 & - \\
\hline Lit/+ não tratado & 2 & $9,40 \pm 3,00$ & 31,9 & - \\
\hline \multicolumn{5}{|l|}{ Lit/lit (15 dias) } \\
\hline salina & 5 & $0,67 \pm 0,27$ & 40,3 & - \\
\hline mGH-gDNA & 8 & $3,90 \pm 1,40$ & 35,9 & $P<0,001$ \\
\hline hGH-gDNA & 6 & $0,55 \pm 0,31$ & 56,4 & n.s. \\
\hline \multicolumn{5}{|l|}{ Lit/lit (45 dias) } \\
\hline salina & 5 & n.d. & - & - \\
\hline mGH-gDNA & 8 & $0,71 \pm 0,31$ & 43,7 & - \\
\hline hGH-gDNA & - & - & - & - \\
\hline \multicolumn{5}{|l|}{ Lit/lit (94 dias) } \\
\hline salina & 5 & $1,30 \pm 0,81$ & 62,3 & - \\
\hline mGH-gDNA & 8 & $1,80 \pm 0,67$ & 37,2 & n.s. \\
\hline hGH-gDNA & - & - & - & - \\
\hline
\end{tabular}

Lit/+, camundongos heterozigotos, cujos níveis de $\mathrm{mGH}=6,60 \pm 2,35 \mathrm{ng} / \mathrm{mL} \quad(\mathrm{n}=12)$ (Peroni e col., 2012); C.V., coeficiente de variação; ${ }^{*}$ Significância em relação ao grupo salina de mesmo tempo de tratamento; n.s., não significativo $(P>0,05)$; n.d., não detectável.

A análise dos parâmetros de crescimento encontra-se na Tabela 4. Houve um aumento significativo do peso corpóreo, quando comparados os pesos finais 
em relação aos iniciais, para os três grupos analisados, verificando-se que o maior aumento foi obtido para os camundongos que receberam o mGH-gDNA $(34,3 \% ; P<0,001)$. Foram também obtidos aumentos significativos das medidas de comprimento realizadas (corpo total, da cauda e do fêmur), e em todos o aumento foi maior para o grupo mGH-gDNA.

Tabela 4: Parâmetros de crescimento de camundongos lit/lit após 94 dias da administração intramuscular de $50 \mu \mathrm{g}$ do plasmídeo UBI-mGH-gDNA (mGHgDNA), UBI-hGH-gDNA (hGH-gDNA) ou salina, seguida de eletroporação

\begin{tabular}{|c|c|c|c|c|}
\hline $\begin{array}{l}\text { Parâmetro de } \\
\text { crescimento }\end{array}$ & $\begin{array}{c}\text { Antes do } \\
\text { tratamento } \\
\text { (média } \pm \text { DP) }\end{array}$ & $\begin{array}{c}\text { Após } \\
\text { tratamento } \\
\text { (média } \pm \\
\text { DP) }\end{array}$ & $\begin{array}{c}\text { Aumento } \\
(\%)^{* 1}\end{array}$ & $\begin{array}{l}\text { Significância } \\
\text { estatística }^{* 2}\end{array}$ \\
\hline \multicolumn{5}{|l|}{ Peso corpóreo (g) } \\
\hline salina & $10,29 \pm 0,96(n=6)$ & $12,77 \pm 0,96$ & 24,1 & $P<0,001$ \\
\hline mGH-gDNA & $10,94 \pm 0,80(n=8)$ & $14,69 \pm 1,62$ & 34,3 & $P<0,001$ \\
\hline hGH-gDNA & $11,39 \pm 0,99(n=7)$ & $14,02 \pm 1,46$ & 23,1 & $P<0,005$ \\
\hline \multicolumn{5}{|l|}{ Compr. total (cm) } \\
\hline salina & & $13,40 \pm 0,48$ & 4,0 & $P<0,025$ \\
\hline mGH-gDNA & $12,89 \pm 0,22(n=8)^{* 3}$ & $14,12 \pm 0,22$ & 9,5 & $P<0,001$ \\
\hline hGH-gDNA & & $13,40 \pm 0,52$ & 4,0 & $P<0,02$ \\
\hline \multicolumn{5}{|l|}{ Compr. cauda } \\
\hline salina & $6,32 \pm 0,19(n=8)^{\star 3}$ & $6,69 \pm 0,38$ & 5,9 & $P<0,025$ \\
\hline $\begin{array}{l}\text { mGH-gDNA } \\
\text { hGH-gDNA }\end{array}$ & & $6,58 \pm 0,23$ & 4,1 & $P<0,02$ \\
\hline \multicolumn{5}{|l|}{ Compr. fêmur (cm) } \\
\hline salina & & $1,14 \pm 0,01$ & 14,0 & $P<0,001$ \\
\hline mGH-gDNA & $1,00 \pm 0,04(n=8)^{* 3}$ & $1,26 \pm 0,07$ & 26,0 & $P<0,001$ \\
\hline hGH-gDNA & & $1,24 \pm 0,05$ & 24,0 & $P<0,001$ \\
\hline
\end{tabular}

${ }^{\text {"1P }}$ Porcentagem de aumento em relação aos valores antes do tratamento; "2Significância em relação aos valores antes do tratamento; ${ }^{*}$ Medidas de comprimento foram realizadas em apenas um grupo de animais, devido a necessidade de anestesia e, no caso da retirada do fêmur, de sacrifício do animal; n.s, não significativo $(P>0,05)$. 


\subsection{Determinação de anticorpos anti-hGH no soro dos camundongos}

Utilizando o método descrito por Bartolini e col., (1977), Dagnaes-Hansen e col. (2002), Glezer e col. (2006) e Bielohuby e col., 2011, a presença do auto anticorpo IgG anti-hGH foi identificada no grupo dos animais imunocompetentes que receberam a injeção do pUBI-hGH-gDNA, seguida de eletroporação. Como controles negativos do ensaio, foram utilizadas amostras de sangue coletadas do grupo salina, e também amostras de animais que receberam injeção de pUBImGH-gDNA para verificar que não houve reação cruzada.

$\mathrm{Na}$ Tabela 5 são apresentadas as contagens (cpm) e porcentagens de ligação específica $(\% \mathrm{~B})$. Observamos claramente que houve a produção de anticorpos somente no grupo que recebeu a injeção do plasmídeo contendo o gene do hGH genômico, quando comparados aos grupos salina e mGH genômico. Nota-se que a presença de anticorpos anti-hGH é, na grande maioria das vezes, maior nos animais 45 dias após a injeção. Estes resultados mostram que existe uma reação imunogênica contra $0 \mathrm{hGH}$ nos animais imunocompetentes. 
Tabela 5: Determinação da presença de anticorpos no soro dos camundongos lit/lit injetados com o plasmídeo UBI-hGH-gDNA (UBI-hGH-1 a UBI-hGH-7), salina (1 e 2) e UBI-mGH-gDNA (UBI-mGH-1 e UBI-mGH-2), considerando positivos os soros cujas contagens foram maiores que a média \pm 2 D.P. das contagens (cpm) obtidas com a injeção de salina

\begin{tabular}{|c|c|c|c|c|c|c|}
\hline Animal & $\begin{array}{c}\text { soro } \\
15^{\circ} \mathrm{dia} \\
(\mathrm{cpm})\end{array}$ & $\begin{array}{c}\% B^{\star 1} \\
15^{\circ} \text { dia }\end{array}$ & $\begin{array}{c}\text { soro } \\
45^{\circ} \text { dia } \\
\text { (cpm) }\end{array}$ & $\begin{array}{c}\% B^{\star 1} \\
\text { 45o dia }\end{array}$ & $\begin{array}{c}\text { soro } \\
94^{\circ} \mathrm{dia} \\
\text { (cpm) }\end{array}$ & $\begin{array}{c}\% B^{\star 1} \\
15^{\circ} \text { dia }\end{array}$ \\
\hline UBI-hGH-1 & 10691 & 39,9 & 15791 & 60,4 & 15794 & 60,4 \\
\hline UBI-hGH-2 & 3723 & 12,0 & 10394 & 38,8 & 12646 & 47,8 \\
\hline UBI-hGH-3 & 9618 & 35,6 & 14511 & 55,2 & 13791 & 52,3 \\
\hline UBI-hGH-4 & 11464 & 43,0 & 17863 & 68,7 & 13527 & 51,3 \\
\hline UBI-hGH-5 & 6276 & 22,3 & 13172 & 49,9 & 11057 & 41,4 \\
\hline UBI-hGH-6 & 2596 & 7,5 & 3863 & 12,6 & 2195 & 5,9 \\
\hline UBI-hGH-7 & 11505 & 43,2 & 13364 & 50,6 & 12757 & 48,2 \\
\hline salina-1 & 1019 & 1,2 & 1139 & 1,7 & 1187 & 1,9 \\
\hline salina-2 & 1273 & 2,2 & 1215 & 2,0 & 1666 & 3,8 \\
\hline UBI-mGH-1 & 1151 & 1,7 & 1554 & 3,4 & 1410 & 2,8 \\
\hline UBI-mGH-2 & 1260 & 2,2 & 1756 & 4,2 & 1397 & 2,7 \\
\hline
\end{tabular}

*1 Porcentagem de ligação específica

A seguir, foram selecionados os soros de dois animais, um que apresentou a ligação mais elevada no dia 45 (hGH-4) e um que apresentou a menor ligação, também no dia 45 (hGH-6), para realizar uma curva de diluição em comparação com o antissoro anti-hGH do NHPP e, consequentemente, determinar o título dos anticorpos formados (Fig. 16). Pode-se verificar que o título dos anticorpos antihGH formados variou numa faixa de 1:100 a 1:3200, enquanto o título do antissoro anti-hGH NHPP, obtido mediante uma técnica apropriada de imunização, é da ordem de 1:800.000. 


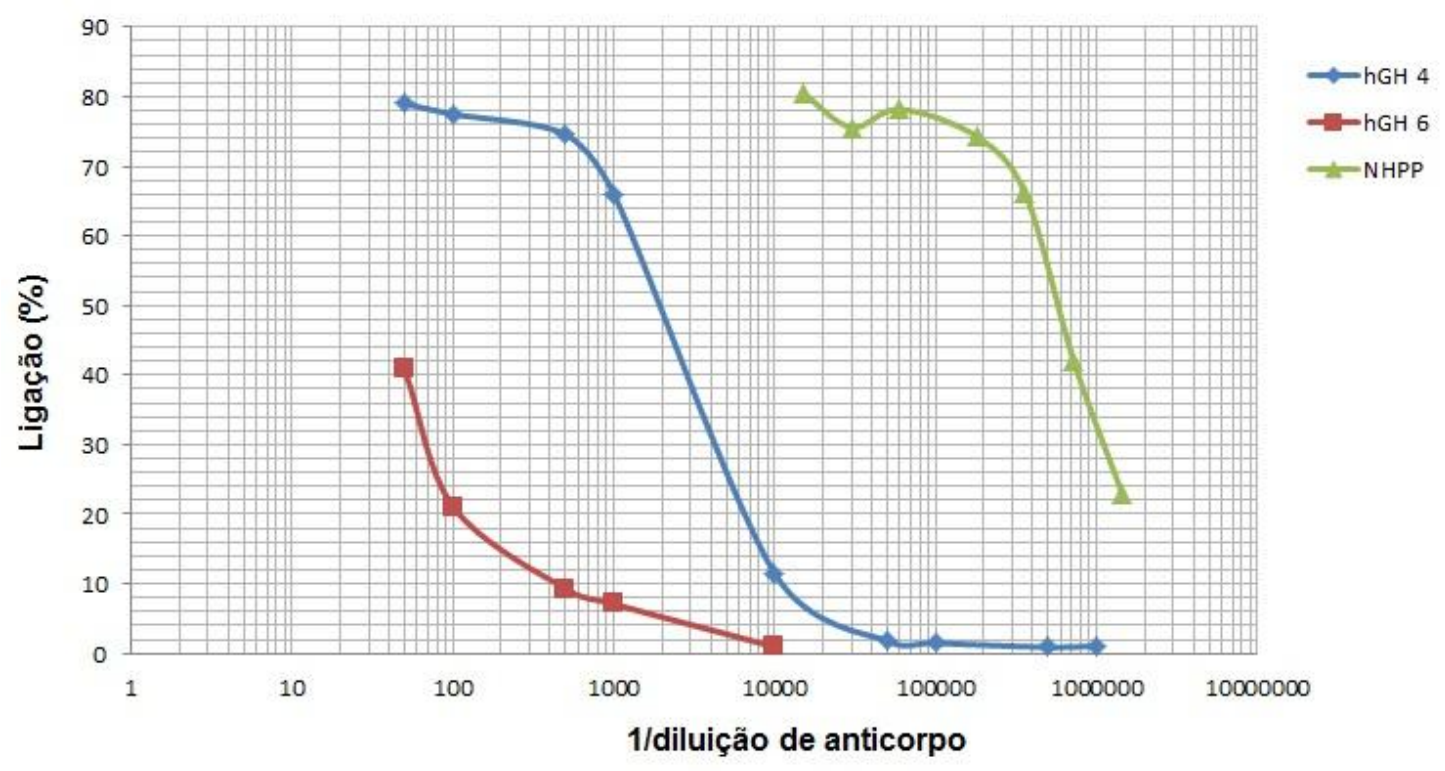

Fig. 16: Curvas de diluição dos soros dos camundongos que receberam o plasmídeo UBI-hGH-gDNA (hGH-6 - dia 45 e hGH4 - dia 45) e do antissoro anti-hGH do NHPP (padrão NHPP). 


\section{DISCUSSÃO}

Neste trabalho foi realizada a construção de um plasmídeo contendo o gene do hormônio de crescimento de camundongo $(\mathrm{mGH})$, utilizando a sequência genômica deste DNA (mGH-gDNA), sob controle do promotor da ubiquitina (UBI). Este plasmídeo (UBI-mGH genômico) foi injetado em camundongos anões imunocompetentes (lit/lit) utilizando a eletrotransferência, para estudar um sistema homólogo de expressão, com o objetivo de obter níveis sustentáveis de mGH e mIGF-I in vivo, em conjunto com a análise de parâmetros de crescimento (peso corpóreo, comprimento total do corpo, da cauda e do fêmur).

Vários trabalhos da literatura apontam para o funcionamento desta técnica de injeção direta de DNA plasmidial (naked DNA) associada à eletrotransferência (Prud'homme e col., 2006; Ratanamart e col., 2006; Gothelf e col., 2010; Gissel, 2010), incluindo resultados obtidos em nosso laboratório em trabalhos anteriores, nos quais foram utilizados o gene do hGH (sequência genômica) em camundongos anões imunodeficientes (lit/scid) (Oliveira e col., 2010; Higuti e col., 2012). No último trabalho realizado por nosso grupo de pesquisa (Higuti e col., 2012), a fim de avaliar os parâmetros de crescimento dos animais tratados, realizou-se um ensaio em comparação com um grupo de animais que recebeu injeções diárias de hGH recombinante (hGH-proteína) na dose de $5 \mu \mathrm{g} / 2$ vezes ao dia/camundongo, durante 28 dias. Neste estudo foi obtido um aumento significativo do peso corpóreo de $23,1 \%(\mathrm{P}<0,01)$ para os animais tratados com o hGH-gDNA e de 35,5\% para os que receberam o hGH - proteína, uma diferença $(P<0,001)$ possivelmente relacionada ao procedimento da eletroporação, uma vez que as inclinações das curvas de crescimento foram praticamente idênticas: 0,094 g/camundongo/dia para o DNA e 0,095 g/camundongo/dia para a proteína. Foi obtido também um aumento significativo do comprimento total do corpo (da ponta do nariz à cauda) de 9,6\% e 15,0\% para o DNA e proteína, respectivamente.

Nesses trabalhos de injeção de naked DNA seguida de eletroporação realizados pelo nosso grupo, foi utilizado o plasmídeo contendo o promotor da ubiquitina $\mathrm{C}$ humana e o gene do hGH genômico. A eficácia deste plasmídeo já havia sido comprovada em outros trabalhos, utilizando injeção de naked DNA por via hidrodinâmica (Dagnaes-Hansen e col. 2002, Sondergaard e col., 2003). A fim 
de verificar uma possível diferença na expressão e duração da proteína de interesse na circulação, neste trabalho foi também utilizado um promotor descrito na literatura como mais forte, o promotor viral CMV. Resultados obtidos na comparação entre os dois diferentes promotores (UBI x CMV), quando injetados no músculo não exposto de camundongos normais, na mesma concentração e seguido pelos mesmos parâmetros de eletroporação, indicaram que houve um aumento de peso significativo dos grupos tratados em relação ao grupo controle (injetado com solução salina), mas não houve diferença significativa de peso quando utilizados os plasmídeos UBI-hGH gDNA, CMV-hGH gDNA ou CMV-hGH cDNA. Níveis baixos de hGH foram porém detectados na circulação desses animais.

Em um estudo utilizando diferentes equipamentos de eletroporação (Cliniporator $\mathrm{x}$ BTX), camundongos normais NMRI foram injetados com os plasmídeos CMV-hGH gDNA ou CMV-hGH cDNA. De acordo com o resultado de porcentagem de incremento de peso, não houve diferença na utilização dos dois eletroporadores.

Após esses resultados obtidos, verificamos que não houve diferença também entre os diferentes plasmídeos com diferentes promotores, e decidimos continuar a utilizar o plasmídeo com promotor da ubiquitina $\mathrm{C}$ em nossos protocolos. A partir daí, iniciou-se a construção de um plasmídeo contendo o gene do $\mathrm{GH}$ de camundongo $(\mathrm{mGH})$ para ser utilizado em protocolos de injeção em camundongos anões: um sistema homólogo. Para isso, foi utilizado o plasmídeo com promotor UBI, para inserção da sequência genômica do mGH.

Com a obtenção da sequência genômica do mGH (mGH-gDNA), sua clonagem no vetor pUC-UBI, e com a secreção de mGH pelas células HEK 293 foi verificado que este plasmídeo é funcionante in vitro, e foram iniciados os ensaios in vivo utilizando este novo plasmídeo. O ensaio in vivo foi inicialmente realizado com a injeção hidrodinâmica do plasmídeo UBI-mGH-genômico, que proporcionou um incremento de peso significativo em duas linhagens de camundongos normais, e demonstrou que a injeção na linhagem de camundongos C57BL6 foi mais eficiente quando comparada à NMRI. Nos camundongos C57BL6 injetados com o plasmídeo UBI-mGH-genômico, o grupo que recebeu o gene do $\mathrm{mGH}$ apresentou um ganho de peso de 66,2 $\pm 12,0 \%$, após 30 dias da injeção. Resultados de injeção hidrodinâmica de 16,67 $\mu \mathrm{g}$ de 
plasmídeo contendo o mesmo promotor e a sequência genômica do hGH em camundongos NOD/SCID, demonstraram um ganho de peso de apenas 20,1 \pm 4,4\% também após 30 dias da injeção (Dagnaes-Hansen e col., 2002), indicando o bom funcionamento do nosso plasmídeo in vivo.

Os resultados obtidos após administração intramuscular e eletroporação in vivo, nos animais lit/lit, mostraram que após 15 dias da injeção seguida de eletroporação, as inclinações das curvas de variação de peso relacionadas ao sistema homólogo $(\mathrm{mGH})$, heterólogo $(\mathrm{hGH})$ e salina foram de 0,130; 0,112 e 0,027 $\mathrm{g} /$ camundongo/dia, respectivamente, e após 94 dias (final do ensaio), as inclinações correspondentes foram 0,041; 0,028 e 0,033 $\mathrm{g} /$ camundongo/dia. Testes estatísticos indicaram que, após 15 dias, as inclinações das duas curvas foram significativamente maiores que a do grupo controle $(P<0,001)$, enquanto que após 94 dias, apenas a inclinação da curva do $\mathrm{mGH}$ foi significativamente maior que a do controle $(P<0,005)$. A inclinação positiva da curva de crescimento do grupo controle é provavelmente devida a um ganho natural de peso nessa linhagem de camundongos anões, que não foi observada em camundongos lit/scid (Oliveira e col., 2010; Higuti e col., 2012). Esses animais também apresentaram níveis significativamente maiores de mIGF-I e mGH quando comparados ao grupo controle, no $15^{\circ}$ dia após o procedimento de injeção, os quais decaíram até o final do ensaio. $O$ aumento de peso relatado para o grupo tratado com mGH-gDNA, após 94 dias, foi de $34,3 \%$, enquanto que os comprimentos nariz-cauda, cauda e do fêmur, medidas de crescimento longitudinal, aumentaram 9,5\%, 5,9\% e $26,0 \%$ respectivamente quando comparados aos do grupo controle.

Em trabalho publicado por Khamaisi e col. (2007), utilizando esse mesmo plasmídeo pUBI-hGH-gDNA, injetado via hidrodinâmica em camundongos hipofisectomizados, foi obtida uma correção no crescimento longitudinal, mediante a normalização do comprimento da tíbia, do tamanho da cauda e do aumento de peso corpóreo. Os autores acreditam que esta normalização pode ter ocorrido em função do crescimento do fígado, que resultou no aumento da vascularização, o que levou à exposição deste órgão a uma maior quantidade de IGF-I produzido e secretado localmente. Quando este plasmídeo foi injetado em camundongos lit/scid, seguido de eletroporação, a dosagem de mIGF-I no soro destes animais, até 50 dias após a administração, apresentou uma concentração de 119,3 \pm 19,0 
ng/mL desta proteína, níveis 4 vezes maiores do que os valores basais, mas não houve normalização dos valores de mIGF-I em relação aos camundongos normais Scid representando ainda aproximadamente 30\% desses níveis (Higuti e col., 2012).

O ensaio de determinação de anticorpos anti-hGH mostrou que os animais imunocompetentes lit/lit que receberam injeção do plasmídeo contendo o gene do hGH, apresentaram uma resposta contra a proteína heteróloga, como verificado anteriormente por Sondergaard e col. (2003), injetando-se o mesmo plasmídeo pUBI-hGH-gDNA em camundongos hipofisectomizados, onde também utilizando o método de precipitação com PEG, foi observado o desenvolvimento de anticorpos contra o hGH. O título dos anticorpos anti-hGH produzidos nos camundongos que receberam o hGH-gDNA (1:100 a 1:3200) é claramente bem menor que o encontrado em outro tipo de estudo (1:33000), no qual camundongos normais da linhagem FVB foram imunizados com hGH recombinante (Bielohuby e col., 2011) e também bem inferiores ao da preparação de anticorpo anti-hGH do NHPP (1:800.000). Em nossos estudos, a presença de anticorpos contra a proteína heteróloga reforça ainda mais a importância da utilização de um sistema homólogo no campo da terapia gênica.

Nossos resultados indicam, portanto, que uma única administração de DNA plasmidial com o gene do mGH foi eficiente, e houve uma alteração fenotípica, mostrando um crescimento longitudinal e secreção de mGH e mIGF-I na circulação dos animais imunocompetentes. Este fato comprova que a transferência gênica in vivo é eficiente para a finalidade de terapia gênica, além de evitar os inconvenientes das manipulações in vitro e posterior transplante in vivo (Ratanamart e col., 2006). A partir destes resultados, este modelo de tratamento homólogo poder ser considerado uma primeira abordagem e um importante suporte para ensaios pré-clínicos testando a administração de naked DNA para o tratamento da deficiência de GH humano. 
A partir dos resultados obtidos podemos concluir que:

- A administração intramuscular de plasmídeos com diferentes promotores (UBI ou CMV) contendo as duas sequências do gene do hGH (genômico $x$ complementar), seguida de eletroporação, proporcionou um incremento de peso altamente significativo de camundongos normais, quando comparado ao do grupo controle;

- Após obtenção da sequência genômica do mGH (mGH-gDNA), sua clonagem no vetor pUC-UBI e expressão de mGH pelas células HEK 293, obtivemos a confirmação que este plasmídeo funciona in vitro, e a partir desta etapa foram iniciados os experimentos utilizando este novo vetor;

- A injeção hidrodinâmica do plasmídeo pUBI-mGH-gDNA proporcionou um incremento de peso significativo em duas linhagens de camundongos normais, e a linhagem de camundongos C57BL6 foi mais eficiente quando comparada à NMRI;

- Os resultados obtidos após administração intramuscular e eletroporação in vivo, nos animais lit/lit, indicaram que o sistema homólogo ( $\mathrm{mGH}$ ) proporcionou alterações fenotípicas de crescimento maiores (aumento de peso corpóreo e de comprimento total, de cauda e do fêmur) devido à secreção de mGH e mIGF-I, quando comparado ao heterólogo (hGH). Estes resultados, incluindo a determinação de anticorpos anti-hGH, nos levam à conclusão de que os animais imunocompetentes apresentam uma resposta imunogênica frente à administração do plasmídeo contendo o gene do GH humano, tornando o uso do sistema homólogo melhor e mais adequado para este tipo de terapia gênica. 


\section{REFERÊNCIAS BIBLIOGRÁFICAS}

ALBA, M.; FINTINI, D.; SALVATORI, R. Effects of recombinant mouse growth hormone treatment on growth and body composition in ghrh knock out mice. Growth Horm. IGF Res. v. 15, n. 4, p. 275-282, 2005.

BARTOLINI, P.; MARQUES DE ASSIS, L.; SCHWARZ, I.; PIERONI, R.R. An accurate determination of human growth hormone content in different pituitary extracts, using a radioimmunoassay with polyacrylamide gel electrophoresis as a bound-free separation system. Clin. Chim. Acta v. 15, n.79 (1), p. 223-236, 1977.

BELL, J. B.; PODETZ-PEDERSEN, K. M.; ARONOVICH, E. L.; BELUR, L. R.; MCIVOR, R. S.HACKETT, P. B. Preferential delivery of the sleeping beauty transposon system to livers of mice by hydrodynamic injection. Nat. Protoc. v. 2, n. 12, p. 3153-3165, 2007.

BELLINI, M. H.; BARTOLINI, P. In vivo bioassay for the potency determination of human growth hormone in dwarf "little" mice. Endocrinology. v. 132, n. 5, p. 2051-2055, 1993.

BELLINI, M. H.; MATHOR, M. B.; DE LUCA, M.; CANCEDDA, R.; BARTOLINI, P. Ultrasensitive in vivo bioassay detects bioactive human growth hormone in transduced primary human keratinocytes. J. Endocrinol. Invest. v. 21, n. 1, p. 16, 1998.

BELLINI, M. H.; PERONI, C. N.; BARTOLINI, P. Increases in weight of growth hormone-deficient and immunodeficient (lit/scid) dwarf mice after grafting of hghsecreting, primary human keratinocytes. FASEB J. v. 17, n. 15, p. 2322-2324, 2003.

BIELOHUBY, M.; SCHAAB, M.; KUMMANN, M.; SAWITZKY, M.; GEBHARDT, R.; BINDER, G.; FRYSTYK, J.; BJERRE, M.; HOEFLICH, A.; KRATZSCH, J.; BIDLINGMAIER, M. Serum IGF-I is not a reliable pharmacodynamic marker of exogenous growth hormone activity in mice. Endocrinology. v. 152, n. 12, p. 4764-4776, 2011. 
BLOQUEL, C.; FABRE, E.; BUREAU, M. F.; SCHERMAN, D. Plasmid DNA electrotransfer for intracellular and secreted proteins expression: New methodological developments and applications. J. Gene Med.v. 6 Suppl 1, n., p. S11-23, 2004.

BROWN, P. A.; BODLES-BRAKHOP, A. M.; POPE, M. A.; DRAGHIA-AKLI, R. Gene therapy by electroporation for the treatment of chronic renal failure in companion animals. BMC Biotechnol. v. 9, n., p. 4, 2009.

CAPLEN, N. J. Gene therapy progress and prospects. Downregulating gene expression: the impact of RNA interference. Gene Ther. v. 11, n. 16, p. 12411248, 2004.

CECCHI, C.R. SECREÇÃO DE HORMÔNIO DE CRESCIMENTO DE CAMUNDONGO POR QUERATINÓCITOS HUMANOS PRIMÁRIOS: PERSPECTIVAS PARA UM MODELO ANIMAL DE TERAPIA GÊNICA CUTÂNEA. 2008. Dissertação (Mestrado). Instituto de Pesquisas Energéticas e Nucleares, São Paulo.

COSTALONGA, E. F.; ANTONINI, S. R.; GUERRA, G., JR.; COLETTA, R. R.; FRANCA, M. M.; BRAZ, A. F.; MENDONCA, B. B.; ARNHOLD, I. J.; JORGE, A. A. Growth hormone pharmacogenetics: The interactive effect of a microsatellite in the igf1 promoter region with the ghr-exon 3 and $-202 \mathrm{a} / \mathrm{c}$ igfbp3 variants on treatment outcomes of children with severe gh deficiency. Pharmacogenomics J. v. 12, n. 5, p. 439-445, 2012.

DAGNAES-HANSEN, F.; HOLST, H. U.; SONDERGAARD, M.; VORUP-JENSEN, T.; FLYVBJERG, A.; JENSEN, U. B.; JENSEN, T. G. Physiological effects of human growth hormone produced after hydrodynamic gene transfer of a plasmid vector containing the human ubiquitin promotor. J. Mol. Med. (Berl). v. 80, n. 10, p. 665-670, 2002.

DANI, S. U. Terapia gênica. Biotecnologia, ciência \& desenvolvimento, v. 12, p. 28-33, 2000. 
DAS, P.; MEYER, L.; SEYFERT, H. M.; BROCKMANN, G.; SCHWERIN, M. Structure of the growth hormone-encoding gene and its promoter in mice. Gene. v. 169, n. 2, p. 209-213, 1996.

ESCOFFRE, J. M.; TEISSIE, J.; ROLS, M. P. Gene transfer: how can the biological barriers be overcome? J. Membr. Biol. v. 236, n. 1, p. 61-74, 2010.

ESCOFFRE, J. M.; PORTET, T.; WASUNGU, L.; TEISSIE, J.; DEAN, D.; ROLS, M. P. What is (still not) known of the mechanism by which electroporation mediates gene transfer and expression in cells and tissues. Mol. Biotechnology, v.41, n.3, p.286-295, 2009.

FATTORI, E.; CAPPELLETTI, M.; ZAMPAGLIONE, I.; MENNUNI, C.; CAlvaruso, F.; ARCURI, M.; RIZZUTO, G.; COSTA, P.; PERRETTA, G.; CILIBERTO, G.; L.A MONICA, N. Gene electro-transfer of an improved erythropoietin plasmid in mice and non-human primates. J. Gene Med. v. 7, n. 2, p. 228-236, 2005.

GARLICK, J. A.; FENJVES, E. S. Keratinocyte gene transfer and gene therapy. Crit. Rev. Oral Biol. Med. v. 7, n. 3, p. 204-221, 1996.

GEHL, J.; MIR, L. M. Determination of optimal parameters for in vivo gene transfer by electroporation, using a rapid in vivo test for cell permeabilization. Biochemical and Biophysical Research Communications, v.261, n.2, p.377-380, 1999.

GILL, D. R.; PRINGLE, I. A.; HYDE, S.C. Progress and prospects: the design and production of plasmid vectors. Gene Ther. v. 16, n. 2, p. 165-171, 2009.

GISSEL, H. Effects of varying pulse parameters on ion homeostasis, cellular integrity, and force following electroporation of rat muscle in vivo. Am. J. Physiol. Regul. Integr. Comp. Physiol. v. 298, n. 4, p. R918-929, 2010.

GLEZER, A.; SOARES, C. R.; VIEIRA, J. G.; GIANNELLA-NETO, D.; RIBELA, M. T.; GOFFIN, V.; BRONSTEIN, M. D. Human macroprolactin displays low biological activity via its homologous receptor in a new sensitive bioassay. J. Clin. Endocrinol. Metab. v. 91, n. 3, p. 1048-1055, 2006. 
GOLZIO, M.; ROLS, M. P.; TEISSIE, J. In vitro and in vivo electric field-mediated permeabilization, gene transfer, and expression. Methods. v. 33, n. 2, p. 126-135, 2004.

GOTHELF, A.; GEHL, J. Gene electrotransfer to skin; review of existing literature and clinical perspectives. Curr. Gene Ther. v. 10, n. 4, p. 287-299, 2010.

HARTMAN, M. L. Phisiological regulators of growth hormone secretion. In Growth Hormone in adults - Physiological and clinical aspects, Cambridge University Press, 2000.

HIGUTI, E.; CECCHI, C. R.; OLIVEIRA, N. A. J.; VIEIRA, D. P.; JENSEN, T. G.; JORGE, A. A. L.; BARTOLINI, P.; PERONI, C. N. Growth responses following a single intra-muscular hgh plasmid administration compared to daily injections of hgh in dwarf mice. Curr. Gene Ther. v. 12, n. 6, p. 437-443, 2012.

HOJMAN, P.; SPANGGAARD, I.; OLSEN, C. H.; GEHL, J.; GISSEL, H. Calcium electrotransfer for termination of transgene expression in muscle. Human Gene Therapy, v.22, n.6, p.753-760, 2011.

HOJMAN, P.; ZIBERT, J. R.; GISSEL, H.; ERIKSEN, J.; GEHL, J. Gene expression profiles in skeletal muscle after gene electrotransfer. BMC Mol. Biol. v. 8, p. 56, 2007.

KHAMAISI, M.; SONDERGAARD, M.; SEGEV, Y.; DAGNAES-HANSEN, F.; JENSEN, T. G.; LANDAU, D.; RAZ, I.; FLYVBJERG, A. Differential effects on kidney and liver growth of a non-viral hgh-expression vector in hypophysectomized mice. Growth Horm. IGF Res. v. 17, n. 4, p. 279-287, 2007.

KHAN, A. S.; DRAGHIA-AKLI, R.; SHYPAILO, R. J.; ELLIS, K. I.; MERSMANN, H.; FIOROTTO, M. L. A comparison of the growth responses following intramuscular ghrh plasmid administration versus daily growth hormone injections in young pigs. Mol. Ther. v. 18, n. 2, p. 327-333, 2010.

LAVIGNE, M. D.; GORECKI, D. C. Emerging vectors and targeting methods for nonviral gene therapy. Expert Opin. Emerg. Drugs. v. 11, n. 3, p. 541-557, 2006. 
LIU, F.; HESTON, S.; SHOLLENBERGER, L. M.; SUN, B.; MICKLE, M.; LOVELL, M.; HUANG, L. Mechanism of in vivo DNA transport into cells by electroporation: electrophoresis across the plasma membrane may not be involved. J. Gene Med. v. 8, n. 3, p. 353-361, 2006.

MARMARY,Y., PARLOW, A.F., GOLDSMITH,C.M., HE, X., WELLNER, R.B., SATOMURA, K., KRIETE, M.F., ROBEY, P.G., NIEMAN, L.K., BAUM, B.J. Construction and in vivo efficacy of a replication deficient recombinant adenovirus encoding murine growth hormone. Endocrinology, v.140, p.260-265, 1999.

MENCK, C.F.M e VENTURA, A.M. Manipulando genes em busca de cura: o futuro da terapia gênica. Revista USP, n.75, p.50-61, 2007.

MIKLAVCIC, D.; MIR, L. M.; THOMAS VERNIER, P. Electroporation-based technologies and treatments. J. Membr. Biol. v. 236, n. 1, p. 1-2, 2010.

MILLER, A. D.; MILLER, D. G.; GARCIA, J. V.LYNCH, C. M. Use of retroviral vectors for gene transfer and expression. Methods Enzymol. v. 217, n., p. 581599, 1993.

MIYAZAKI, S.; MIYAZAKI, J. In vivo DNA electrotransfer into muscle. Dev. Growth Differ. v. 50, n. 6, p. 479-483, 2008.

NARDI, N.B.; TEIXEIRA, L.A.; DA SILVA, E.F.A. Terapia gênica. Ciência \& saúde coletiva, v.7, p.109-116, 2002.

OLIVEIRA, N. J. A.;DESENVOLVIMENTO DE MODELOS ANIMAIS DE TERAPIA GÊNICA PARA HORMÔNIO DE CRESCIMENTO UTILIZANDO QUERATINÓCITOS TRANSDUZIDOS E INJEÇÃO DIRETA DE DNA PLASMIDIAL. 2010. Tese (Doutorado). Instituto de Pesquisas Energéticas e Nucleares, São Paulo.

OLIVEIRA, N. A. J.; CECCHI, C. R.; HIGUTI, E.; OLIVEIRA, J. E.; JENSEN, T. G.; BARTOLINI, P.; PERONI, C. N. Long-term human growth hormone expression and partial phenotypic correction by plasmid-based gene therapy in an animal 
model of isolated growth hormone deficiency. J. Gene Med. v. 12, n. 7, p. 580585, 2010.

OliVEIRA, J. E.; SOARES, C. R. J.; PERONI, C. N.; GIMBO, E.; CAMARGO, I. M. C.; MORGANTI, L.; BELLINI, M. H.; AFFONSO, R.; ARKATEN, R. R.; BARTOLINI, P.; RIBELA, M. T. C. P. High-yield purification of biosynthetic human growth hormone secreted in Escherichia coli periplasmic space. $J$. Chromatography A, v.852, n.2, p.441-450, 1999.

PERONI, C. N.; GOUT, P. W.; BARTOLINI, P. Animal models for growth hormone gene therapy. Curr. Gene Ther. v. 5, n. 5, p. 493-509, 2005.

PERONI, C. N.; CECCHI, C. R.; DAMIANI, R.; SOARES, C. R.; RIBELA, M. T.; DO ROCIO ARKATEN, R.; BARTOLINI, P. High-level secretion of growth hormone by retrovirally transduced primary human keratinocytes: Prospects for an animal model of cutaneous gene therapy. Mol. Biotechnol. v. 34, n. 2, p. 239245, 2006.

PERONI, C. N.; CECCHI, C. R.; ROSAURO, C. W.; NONOGAKI, S.; BOCCARDO, E.; BARTOLINI, P. Secretion of mouse growth hormone by transduced primary human keratinocytes: prospects for an animal model of cutaneous gene therapy. J. Gene Med. v. 10, n. 7, p. 734-743, 2008.

PERONI, C.N.; OLIVEIRA, N.A.J.; CECCHI, C.R.; HIGUTI, E. and BARTOLINI, P. Different ex vivo and direct in vivo DNA administration strategies for growth hormone gene therapy in dwarf animals, Targets in Gene Therapy, Ed. Yongping You, Rijeka, Croácia, InTech, 2011. Disponível em: http://www.intechopen.com/books/targets-in-gene-therapy/different-ex-vivo-anddirect-in-vivo-dna-administration-strategies-for-growth-hormone-gene-therapy-i

PERONI, C. N.; HAYASHIDA, C. Y.; NASCIMENTO, N.; LONGUINI, V. C.; TOLEDO, R. A.; BARTOLINI, P.; BOWERS, C. Y.TOLEDO, S. P. Growth hormone response to growth hormone-releasing peptide-2 in growth hormone-deficient little mice. Clinics. v. 67, n. 3, p. 265-272, 2012.

PHILMANN, M.; ASKOU, A. L.; AAGAARD, L.; BRUUN, G. H.; SVALGAARD, J. D.; HOLM-NIELSEN, M. H.; DAGNAES-HANSEN, F.; BEK, T.; MIKKELSEN, J. 
G.; JENSEN, T. G.; CORYDON, T. J. Adeno-associated virus-delivered polycistronic microRNA-clusters for knockdown of vascular endothelial growth factor in vivo. J. Gene Med. v. 14, n. 5, p. 328-338, 2012.

PRUD'HOMME, G. J.; GLINKA, Y.; KHAN, A. S.; DRAGHIA-AKLI, R. Electroporation-enhanced nonviral gene transfer for the prevention or treatment of immunological, endocrine and neoplastic diseases. Curr. Gene Ther. v. 6, n. 2, p. 243-273, 2006.

QIN, J. Y.; ZHANG, L.; CLIFT, K. L.; HULUR, I.; XIANG, A. P.; REN, B. Z.LAHN, B. T. Systematic comparison of constitutive promoters and the doxycyclineinducible promoter. PLoS One. v. 5, n. 5, p. e10611, 2010.

RATANAMART, J.; SHAW, J. A. Plasmid-mediated muscle-targeted gene therapy for circulating therapeutic protein replacement: $A$ tale of the tortoise and the hare? Curr. Gene Ther. v. 6, n. 1, p. 93-110, 2006.

RIBELA, M. T.; MURATA, Y.; MORGANTI, L.; TONIOLO, D.; BARTOLINI, P. The use of recombinant human growth hormone for radioiodination and standard preparation in radioimmunoassay. J. Immunol. Methods. v. 159, n. 1-2, p. 269274, 1993.

RIZZUTO, G.; CAPPELLETTI, M.; MAIONE, D.; SAVINO, R.; LAZZARO, D.; COSTA, P.; MATHIESEN, I.; CORTESE, R.; CILIBERTO, G.; LAUFER, R.; LA MONICA, N.; FATTORI, E. Efficient and regulated erythropoietin production by naked DNA injection and muscle electroporation. Proc. Natl. Acad. Sci. U S A. v. 96, n. 11, p. 6417-6422, 1999.

ROBBINS, P. D.; GHIVIZZANI, S. C. Viral vectors for gene therapy. Pharmacol. Ther. v. 80, n. 1, p. 35-47, 1998.

SONDERGAARD, M.; DAGNAES-HANSEN, F.; FLYVBJERG, A.; JENSEN, T. G. Normalization of growth in hypophysectomized mice using hydrodynamic transfer of the human growth hormone gene. Am. J. Physiol. Endocrinol. Metab. v. 285, n. 2, p. E427-432, 2003. 
STRACHAN, T. \& READ, A.P Strachan, T. \& Read, A.P. in Human molecular genetics: Gene therapy and others terapeutics approach. Taylor \& Francis Group Press, London, UK. v.2, p.515-543, 1999.

VERMA, I. M.; WEITZMAN, M. D. Gene therapy: twenty-first century medicine. Annu. Rev. Biochem. v. 74, n., p. 711-738, 2005.

ZANINELLI, D.C.T., MEISTER, L.H.F, RADOMINSKI, R.B, BORBA, V.C.Z., SOUZA, A.M., BOGUSZEWSKI, C.L. Eficácia, seguranca e aderência ao tratamento de longo prazo com hormônio de crescimento $(\mathrm{GH})$ em adultos com deficiência de GH. Arq. Bras. Endocrinol. Metab. v. 52, n. 5, p. 879-888, 2008. 